CNHL -2311

$U C-66 i$

\title{
GEOTHERIIAL ENERGY POTENTIAL FOR DISTRICT AND PROCESS HEATING APPLICATIONS IN THE U.S. - AN ECONOMIC ANALYSIS
}

by

C. H. Bloomster

L. L. Fassbender

C. L. McDonald

August 1977

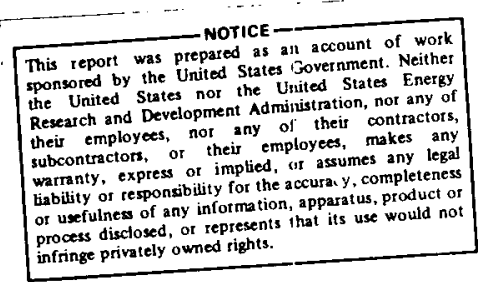

BATTELLE

Pacific Northwest Laboratories

Richland, WA 99352 


\section{DISCLAIMER}

This report was prepared as an account of work sponsored by an agency of the United States Government. Neither the United States Government nor any agency Thereof, nor any of their employees, makes any warranty, express or implied, or assumes any legal liability or responsibility for the accuracy, completeness, or usefulness of any information, apparatus, product, or process disclosed, or represents that its use would not infringe privately owned rights. Reference herein to any specific commercial product, process, or service by trade name, trademark, manufacturer, or otherwise does not necessarily constitute or imply its endorsement, recommendation, or favoring by the United States Government or any agency thereof. The views and opinions of authors expressed herein do not necessarily state or reflect those of the United States Government or any agency thereof. 


\section{DISCLAIMER}

Portions of this document may be illegible in electronic image products. Images are produced from the best available original document. 


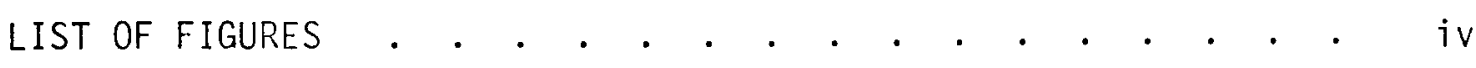

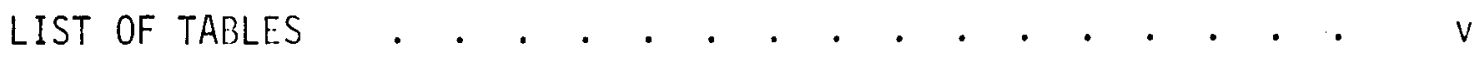

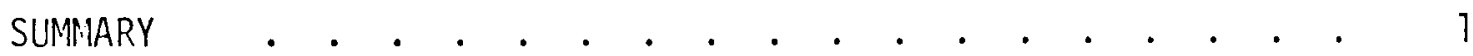

INTRODUCTION $\cdot$ •

POTENTIAL NONELECTRIC APPLICATIONS OF GEOTHERMAL ENERGY • • • 4

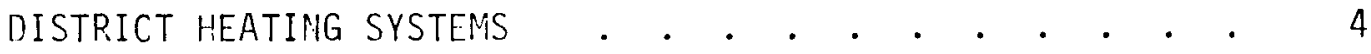

INDUSTRIAL PROCESS HEAT • • • • • • • • • • • • •

SYSTEMS ANALYSIS OF GEOTHERMAL ENERGY COSTS • • • • • • • • $\quad 9$

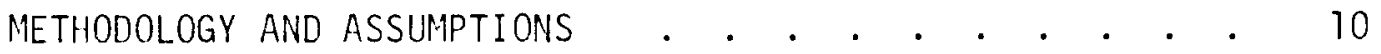

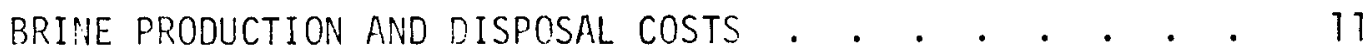

Load Factor . . . . . . . . . . . . . 14

We 11 Productivity and Well Cost . . . . . . 15

We11 Life . . . . . . . . . . • • • . 17

Disposal Costs . . . . . . . . . . . . . . 17

FLUID TRANSMISSION COSTS . . . . . . . . . . . . 18

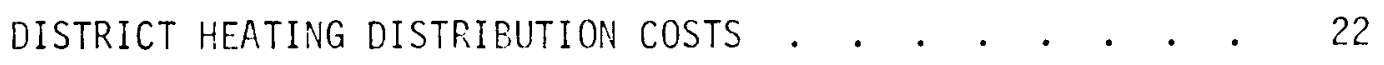

Climate . . . . . . . . . • • • . 23

Community Characteristics . . . . . . . . . 25

New Construction . . . . . . . . . . . 26

Established Areas . . . . . . . . . . . . 26

The Load Duration Curve . . . . . . • . . . 27

PROCESS HEAT RETROFITTING AND UTILIZATION • • • • • • $\quad 28$

COMPARATIVE COSTS OF CONVENTIONAL ENERGY SUPPLIES • • • • • • $\quad 31$

POTENTIAL GEOTHERMAL ENERGY SUPPLY . • • • • • • • • • • • • 34

SUPPLY CURVES FOR SPACE HEATING • • • • • • • • • • • 34

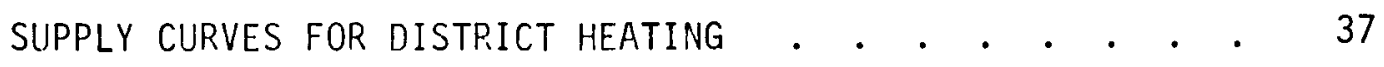

SUPPLY CURVES FOR PROCESS HEATING • • • • • • • • • • • 39

POTENTIAL DEIAND FOR GEOTHERMAL ENERGY . • • • • • • . • . 41

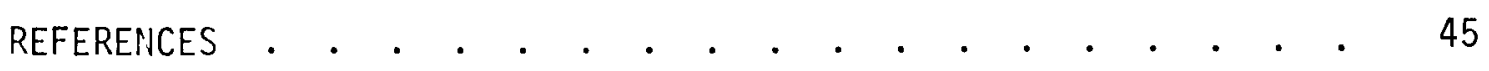

APPENDIX A -.. HOT WATER FROH COAL . . . . . . . . . . . . A-1

APPENDIX B - - TOTAL POPIULATION WITHIN 50 MILES OF GEOTHERMAL

RESOURCES • . . . . . . . . . . . . B 


\section{LIST OF FIGURES}

1 Effect of Financing on Annual costs . . . . . . . . 12

2 Energy Costs at the Wellhead . . . . . . . . . 14

3 Effect of Load Factor on Cost . . . . . . . . . . 15

4 Effect of Fluid Temperature, Well Flow Rate and liell cost on Production Costs . . . . . . . . . . . 16

5 Reservoir Costs as a Function of Well Life. . . . . . 17

6 Energy Transmission Costs . . . . . . . . . . . . 19

7 Transmission Line Capital Costs . . . . . . . . . 20

8 Energy Transmission Costs . . . . . . . . . . . 22

9 Capital Costs for District Heating Distribution System . . 24

10 Energy Distribution Costs . . . . . . . . . . . 24

11 Energy Distribution Costs . . . . . . . . . . . 25

12 Load Duration Curve . . . . . . . . . . . . . 27

13 Production and Transmission costs as a Function of Reject Temperature . . . . . . . . . . . . . . . . 30

14 Location of Geothermal Resources in the $90^{\circ} \mathrm{C}$ to $150^{\circ} \mathrm{C}$ Range 35

15 Potential Supply of Geothermal Energy in the $90^{\circ} \mathrm{C}$ to $150^{\circ} \mathrm{C}$ Range . . . . . . . . . . . . . . 35

16 Supply Curve at the Point of Delivery for Geothermal Space Heating . . . . . . . . . . . . . . . . 36

17 Supply Curve for Urban District Heating . . . . . . 38

18 Supply Curve for Suburban District Heating . . . . . 39

19 Supply Curve for Geothermal Process Heating . . . . . 40

20 Current District Heating Demand . . . . . . . . 43

B-1 Incorporated Areas and Unincorporated Areas of 1,000 or
More Within 50 Miles of the Resource. B-2 


\section{LIST OF TAELEES}

1 Estimated Heating Energy Use in the United States in $1968 \quad 6$

2 Financing and Tax Assumptions . . . . . . . . . . 11

3 Key Brine Production Parameters . . . . . . . . . 12

4 Key Transmission System Parameters . . . . . . . . 18

5 Transmission System Design Configurations . . . . . . 21

6 Key District Heating Parameters . . . . . . . . . 23

7 Shell-and-Tube Heat Exchanger Costs . . . . . . . . 29

8 Energy Prices for Conventional Fuels . . . . . . . . 31

9 Energy Costs for Residential Heating (In 1975 Dollars) ( $\$ / G J$ of Space Heat Delivered) . . . . . . . . . . . 32

101985 Projected Coal Prices (In Constant 1975 Dollars) . . 33

11 Hot-Water Convection Systems From $90^{\circ} \mathrm{C}$ to $150^{\circ} \mathrm{C}$. . . . 35

12 Potential Annual Energy Production for Space Heating From $90^{\circ} \mathrm{C}-150^{\circ} \mathrm{C}$ Hot-Water Convection Systems . . . . . . 36

13 Potential Annual Energy Production for Process Heating From $90^{\circ} \mathrm{C}$ to $150^{\circ} \mathrm{C}$ Hot-Water Convection Systems . . . . . . 41

14 Current Population Surrounding Geothermal Resources in the $90^{\circ} \mathrm{C}$ to $150^{\circ} \mathrm{C}$ Range . . . . . . . . . . . . . 41

15 Potential Existing Demand for District Heating . . . . . 42

16 Potential Existing Demand for Process Heating . . . . . 44

A-1 Annual Energy Costs for Hot Water From Coal . . . . . A-2

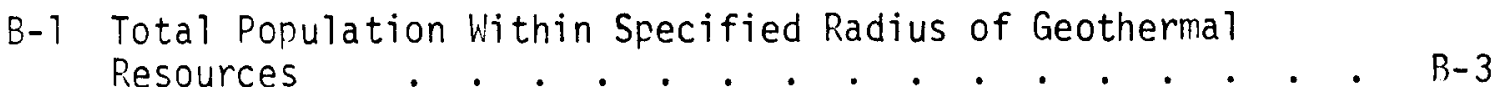


Geothermal energy is competitive for space and process heating applications over significant distances when employed on a large scale to serve concentrated markets. Under these conditions geothermal energy from $90^{\circ} \mathrm{C}$ to $150^{\circ} \mathrm{C}$ hydrothermal resources should be economically competitive for high-density urban district heating out to distances of 50 miles from the wellhead. From these same resources geothermal energy should be competitive for district heating in lowdensity urban and suburban areas out to 50 miles from most resources when alternative residential heating costs exceed $\$ 8 / \mathrm{GJ}$ (a) Resources in the $130^{\circ} \mathrm{C}$ to $150^{\circ} \mathrm{C}$ range should be competitive for process heating out to $30 \mathrm{miles}$ from the well thead.

Supply curves (price-quantity relationships) were developed for both process heating and district heating applications for distances out to $50 \mathrm{miles}$. The $90^{\circ} \mathrm{C}$ to $150^{\circ} \mathrm{C}$ hydrothermal resources, which were identified in the assessment of geothermal resources by the U.S. Geological survey, contain usable energy for space and process heat equivalent to 50 billion barrels of oil. The potential demand for space and process heat near these hydrothermal resources is large; over $10 \%$ of the U.S. population resides within 40 miles of the resources.

The sensitivity of production costs to the important factors of production was determined. The most important factors are well costs, well flow rate, resource temperature, distance separating demarid and supply, population density, size of demand, and the system load factor. The supply of geothermal energy for district or process heating is capital intensive; over $75 \%$ of the production costs are fixed costs related to the initial capital investment.

Although no technology breakthroughs are required in the utilization of geothermal energy for these nonelectric applications, technological advances are needed to reduce costs and increase the distances over which geothermal energy can be competitive. Significant cost reductions would be

\footnotetext{
(a) 1 gigajoule $(G J)=948,000$ Btu.
} 
achieved by reducing well-drilling costs, stimulating well flow rates, increasing productivity in pipeline construction, developing low cost pipeline materials, reducing fluid disposal costs and developing low cost energy storage capacity.

Institutional deterrents to widespread nonelectric applications of geothermal energy will probably be significant. Among these will be the acquisition of rights-of-way, the need to organize concentrated markets, and price competition from the conventional fuels based on average cost rather than marginal cost. 


\section{GEOTHERIIAL ENERGY POTENTIAL FOR DISTRICT AND PROCESS \\ HEATING APPLICATIONS IN THE U.S. - AN ECONOMIC ANALYSIS}

\section{INTRODUCTION}

This report provides a preliminary economic assessment of the potential for geothernal energy to supply space and process heat in the U.S. Currently, the use of geothermal energy for space and process heating in the U.S. is insignificant - less than 1000 dwellings are heated in Klamath Falls, Oregon and Boise, Idaho.

Worldwide, these applications of geothermal energy are much more extensive. In Iceland, municipal district heating systems use geothermal energy to heat the homes of more than 100,000 people. Geothermal district heating systems are also located in France, Hungary, Japan, and the USSR. other district heating systems based on fossil fuels are also common in Europe. Many countries have geothemal process heat installations, but combined the total energy currently supplied is small.

Rising energy prices have spawned increased interest in geothermal energy for process and district heating. In the past, both were severely limited in development by competition from low-priced alternatives. Now, with low-priced alternatives no longer available, geothermal energy may be economically competitive in many locations.

This report has three principal objectives: 1) to define the technical and economic conditions which would encourage the substitution of geothermal energy for space and process heating, 2) to derive supply schedules for geothermal nonelectric applications, and 3) to assess the potential demand for geothermal energy near identified geothermal resources.

The geothermal resource upon which this study is based is the $90^{\circ} \mathrm{C}$ to $150^{\circ} \mathrm{C}$ hydrothermal resource identified by the U.S. Geological Survey. (1) This resource, which contains an enormous amount of energy, is too low in temperature for electricity generation but has good potential for nonelectric uses. Estimates of the energy content, characteristics, and locations of the resource are derived from data in the USGS assessment. 
Our estimates of production costs will be obtained using the GEOCITY(2) model. This model simulates geothermal district heating systems. GEOCITY designs and estimates the current costs of these systems. Process heating applications are also simulated with the GEOCITY model as large point source users. The economics of district heating and process heating applications are affected by many factors. With the GEOCITY model the impact of these factors on production costs can be analyzed rapidly in a systematic framework.

\section{POTENTIAL NONELECTRIC APPLICATIONS OF GEOTHERMAL ENERGY}

Although current nonelectric usage of geothermal energy in the U.S. is miniscule, a large potential demand exists if geothermal energy costs become competitive with alternative energy sources. Large uses for geothermal energy could develop for district and process heating, greenhouse heating, balneology, soil warming, and fish-rearing. However, this study will consider only district and process heating applications.

\section{DISTRICT HEATING SYSTEMS}

In district heating systems a network of insulated pipes distributes heat, using either hot water or steam, to commercial and residential customers from a central distribution point. European systems use hot water almost exclusively. Existing U.S. systems primarily use steari. Ir singlepipe, once-through distribution systems, fluid disposal is through a sewer system. In two-pipe systems, the fluid is recirculated, conserving the fluid and residual heat. Two-pipe systems cost approximately $20 \%$ more than singlepipe systems.

Geothermal district heating systems use hot water. Besides the distribution system, the geothermal system includes wells for hot water production and insulated pipes for fluid transmission between the wells and the central distribution point. Submersible pumps are usually used to increase the 
flow from the wells. Other pumps are used to overcome head losses in the transmission and distribution pipes. Supplemental heating capacity is usually provided to handle peak demands. Storage tanks absorb flow fluctuations and provide limited reserve capacity. If the geothermal water is contaminated, heat exchangers may be used. If surface disposal of the water is not feasible, reinjection wells will be required.

A single-pipe distribution system is generally preferred when the geothermal energy is abundant and (1) the water is pure enough to be circulated through the distribution system and disposed of through a sewer system, or (2) the geothermal fluid is contaminated but sufficient fresh water is available for heat transfer, circulation, and disposal. Two-pipe, recirculating systems are preferred when the supplies of energy or potable water are the limiting factors of production.

The geothermal district heating systems in Iceland are mostly singlepipe systems. In most systems the geothermal water is potable. In one system the heat is transferred from brine to fresh water. The French geothermal district heating systems are mostly two-pipe systems; heat exchangers are used and the brine is reinjected. Future U.S. systems will probably be predominately two-pipe systems in the interest of both energy and water conservation.

Geothermal district heating systems are capital intensive. The principal costs are initial investment costs for wells, pipes, pumps, meters, valves, and storage tanks. Operating expenses are low in ccmparison and consist of pumping power, system maintenance and control, and meter reading.

INDUSTRIAL PROCESS HEAT

Under favorable economic conditions, geothermal energy could supply process heat to many industries. According to Reistad, (3) $38 \%$ of the U.S. heating energy consumption (Table 1 ) is for commercial and industrial app $1 i$ cations in the $100^{\circ} \mathrm{C}$ to $200^{\circ} \mathrm{C}$ temperature range. In this study, we are concerned only with geothermal resources up to $150^{\circ} \mathrm{C}$, since these resources are expected to have potential only for space and process heat. Nonetheless, 
TABLE 1. Estimated Heating Energy Use in the United States in 1968

Selected

Temperature

Range, ${ }^{\circ} \mathrm{C}$

$50-74$

$75-99$

$100-124$

$125-149$

$150-174$

$175-199$

$200-224$

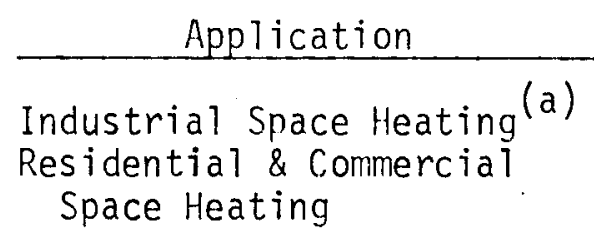

Residential Water Heating Commercial water Heating other Industries(a)

Commercial Air Conditioning Range Cooking Clothes Drying $(a)$ Food \& Kindred (a)
Other Industries

Food \& Kindred (a)

Petroleum (a) Chemcial \& Allied(a)

other Industries(a)

Residential Refrigeration

Commercial Refrigeration

Industrial Refrigeration

Residential Air Conditioning

Petroleum(a)

Paper \& Al lied (a)

Chemical \& Alljed (a)

Food \& Kindred
Other Industries

Paper \& Allied (a)

Chemical \& Allied(a)

Petroleum(a)

other Industries (a)

Chemicàl \& Allied (a)

Petroleum(a)

other Industries (a)
Energy Use

$10^{15} \mathrm{Btu}$

1.223

10.857

$\overline{12.080}$

1.736

0.653

0.116

$\overline{2.505}$

1.113

0.427

0.208

0.405

0.408

2.561

0.405

0.384

0.328

1.223

2.340

0.692

0.670

0.100

0.427

0.384

0.302

0.274

0.090

1.106

$\overline{4.045}$

0.703

0.274

0.058

1.106

2.741

0.082

0.067

0.116

$\overline{0.265}$ 
TABLE 1. Continued

\begin{tabular}{l} 
Selected \\
Temperature \\
Range, ${ }^{\circ} \mathrm{C}$ \\
\hline
\end{tabular}

225-249

\begin{tabular}{l} 
Applications \\
\hline $\begin{array}{l}\text { Chemical \& Allied (a) } \\
\text { Petroleum(a) } \\
\text { Other Industries (a) }\end{array}$
\end{tabular}

$$
\begin{gathered}
\begin{array}{c}
\text { Energy Use } \\
10^{75} \text { Btu }
\end{array} \\
\hline \begin{array}{c}
0.082 \\
0.067 \\
0.116 \\
0.265
\end{array}
\end{gathered}
$$

(a) Process steam use in sector.

SOURCE: G. M. Reistad, Analys is of Potential Nonelectrical Applications of Geothermal Energy and Their Place in the National Economy. UCRL-51747, Lawrence Livermore Laboratory, Berkeley, CA, 1975. 
$19 \%$ of U.S. heating energy consumption is in the $100^{\circ} \mathrm{C}$ to $150^{\circ} \mathrm{C}$ temperature range. Geothermal resources above $150^{\circ} \mathrm{C}$, which are outside the scope of this study, are considered to have good potential for commercial electric power production; these higher temperature resources could also provide process heat to favorably located industries.

The substitution of geothermal energy for conventional energy in process heating involves replacing the conventional fuel supply and the plant furnace and boiler units with a delivery system for geothermal energy. The geothermal delivery system includes production wells, fluid transmission pipes, and heat exchangers, if required. The production wells and fluid transmission systems are similar to their counterparts for district heating applications.

If the mineral content of the gecthermal fluid is high, heat will be transferred from the brine to purer process water. Depending on the location of the fresh water source, the heat exchanger can be located at the wellhead, at the plant site, at the disposal site, or at some other more favorably located site. If the geothermal fluid is sufficiently pure, it can be circulated through the plant, eliminating the need for the heat exchanger. Also, if pure enough, the geothermal fluid can be disposed of through the existing sewer system or perhaps used consumptively in the process, reducing or eliminating the reed for fresh process water.

In applications in which the process heat is normally supplied by hot water, the in-plant circulation systems should be readily adaptable to geothermal energy and the incremental retrofitting cost for the geothermal system would be minimal.

Process heating applications differ from space heating in that (1) the brine reject temperature is higher, and (2) climate has little or no direct impact on energy demand. However, the impact of seasonal variations in the production cycle may be significant. In some respects, process heating applications would tend to have economic advantages over district heating because the heat demand tends to be more concentrated and the average load factor tends to be higher. On the other hand, process heating would 
tend to have an economic disadvantage because the minimum temperature of utilization is higher and less of the potentially available energy is consumed. For district heating applications, the geothermal brine in this study is rejected at $38^{\circ} \mathrm{C}$. For process heating applications, the reject temperature in this study is $100^{\circ} \mathrm{C}$. Actual reject temperatures may vary from these typical values depending on the characteristics of the specific application.

Geothermal process heating applications are also capital intensive. The princinal costs are initial investment costs. Operating expenses are relatively low.

\section{SYSTEMS ANALYSIS OF GEOTHERMAL ENERGY COSTS}

A wide variation can be expected in the range of potential geothermal energy costs for district heating and process heating applications. The range of costs is determined by the characteristics of the resource, the characteristics of the demand and the distance separating the resource and the demand. In this section we develop costs for each of the main parts of the production process. He also determine the sensitivity of these costs to several significant parameters under a consistent set of assumptions.

The four main parts of the production process for geothermal district heating are: production, transmission, distribution, and disposal. The costs for distribution depend on the size of the population, the population density, and the climate. Transmission costs are related primarily to distance, but the temperature of transmission, size of demand, and load factor are also important. Production costs depend primarily on well drilling costs, wellhead temperature, flow rate, and the load factor. Disposal costs vary primarily with the disposal method: consumptive use and surface disposal would incur only negligible costs; disposal by reinjection would incur higher costs which would vary with the same factors as the costs of production. 
Geothermal process heating costs are derived from four similar categories: production, transmission, retrofitting, and disposal. Factors affecting production, transmission, and disposal costs for process heating differ little from district heating. Retrofitting costs will usually be low and will mainly be related to the size of the heat exchanger, if required.

METHODOLOGY AND ASSUMPTIONS

The basis for our geothermal energy cost analysis is the unit cost of energy which will recover all the costs of production - capital investment, operating expenses, taxes, and the specified rates of return on capital. This unit cost of energy can be directly compared with the costs for conventional energy sources. The gigajoule (GJ) will be our energy unit. A gigajoule $\left(10^{9}\right.$ joules) is approximately equal to one million British thermal units, actually $948,000 \mathrm{Btu}$. Our focus is on the economics of substituting geothermal energy, based on production costs, for conventional energy sources. Institutional and psychological barriers to substitution are outside the scope of this study.

The calculation of the unit cost of energy is based on life cycle costing and discounted cash flow analysis. The GEOCITY model is used for these calculations. The unit cost of energy is derived from the following expression:

$$
c=\frac{\sum_{n=1, n y} P W_{n} \cdot\left(\operatorname{CAP}_{n}+\operatorname{EXP}_{n}+\operatorname{TAX}_{n}\right)}{\sum_{n=1, n y} P W_{n} \cdot \text { ENERGY }_{n}}
$$

where: $\quad C=$ unit cost of energy

$$
\begin{aligned}
\text { ny } & =\text { useful } 1 \text { ife, years } \\
C A P & =\text { capital cost } \\
E X P & =\text { annual operating expenses } \\
T A X & =\text { annual taxes } \\
P W & =\text { present worth factor } \\
\text { ENERGY } & =\text { annual energy production } \\
n & =\text { year }
\end{aligned}
$$


The geothermal energy is assumed to be provided by firms having the capitalization and financial characteristics shown in Table 2. The firms would typically be a large oil comnany operating the reservoir and a large investor-owned utility operating the transmission and distribution system. The weighted after tax cost of capital is $7.2 \%$ for the utility and $10.3 \%$ for the oil company. The equivalent annual fixed charge rate is about 15\% for the utility and about 20\% for the oil company. The large utility and large oil company are intermediate in the cost of capital among entities that might supply and distribute geothermal energy. These range from municipal utilities with their low cost of capital to small resource exploration firms which rely primarily on venture capital (Figure 1). Assumptions affecting taxes included expensing intangible drilling costs, a 10\% irvestment tax credit, and accelerated (sum-of-theyears' digits) depreciation. All cost estimates are in 1977 dollars unless otherwise stated.

\section{TABLE 2. Financing and Tax Assumptions}

\begin{tabular}{lcc} 
& $\begin{array}{c}\text { Reservoir } \\
(\%)\end{array}$ & $\begin{array}{c}\text { Transmission and } \\
\text { Distribution System } \\
(\%)\end{array}$ \\
\cline { 2 - 3 } Capitalization & & \\
\cline { 2 - 2 } Debt & 42 & 59 \\
$\quad$ Equity & 58 & 41 \\
Bond Interest Rate & 8 & 8 \\
Return on Equity & 15 & 12 \\
Federal Income Tax Rate & 48 & 48 \\
State Income Tax Rate & 7 & 7 \\
Property Tax Rate & 2.5 & 2.5 \\
Royalty Payment & 10 & - \\
Revenue Tax Rate & -- & 4
\end{tabular}

BRINE PRODUCTION AND DISPOSAL COSTS

Brine production costs are primarily related to the cost of the producing wells, the well flow rate, the temperature, the well life, and the average annual load factor. The last four factors determine the energy production rate. Our cost analyses cover the expected range of values for these major factors of production (Table 3 ). 


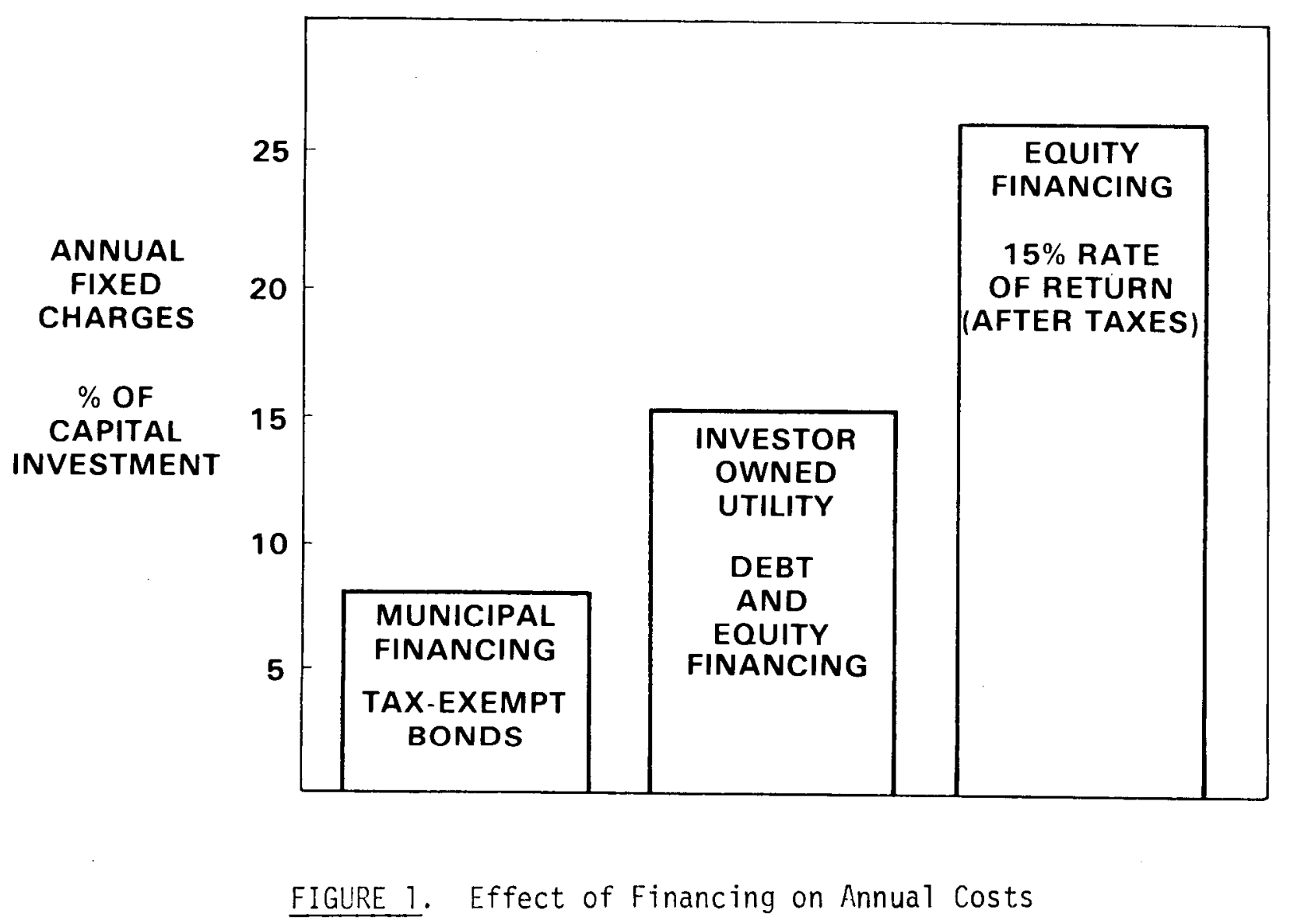

TABLE 3. Key Brine Production Parameters

\section{Parameter}

Temperature

Flow Rate

We11 Cost

Well Life

Load Factor
Reference Values

$120^{\circ} \mathrm{C}$

$140,000 \mathrm{~kg} / \mathrm{hr}$

$\$ 500,000$

30 years

$50 \%$
Expected Range

$$
\begin{aligned}
& 90-150^{\circ} \mathrm{C} \\
& 140,000-230,000 \mathrm{~kg} / \mathrm{hr} \\
& \$ 250,000-\$ 1,000,000 \\
& 10-50 \text { years } \\
& 10-100 \%
\end{aligned}
$$


The costs for geothermal energy production derive mainly from the initial cost of the producing wells. Operating expenses, including well redrilling, maintenance, and pumping costs will usualiy be small in proportion to the initial cost. Only when well lifetimes are extremely short will production costs be significantly affected by continuing costs; i.e., the costs for replacement wells. Our cost estimates include a gathering system to bring the flow from several wells to a central point. The cost estimates also include a provision $(10 \% / \mathrm{GJ})$ for the cost and operating expenses for submersible downhole pumps. Nearly all of these resources are expected to require pumping to achieve economic flow rates.

We11 costs have a significant impact on the cost of energy (Figure 2). The upper line shows the minimum termperature and economic flow conditions expected for these geothermal resources. The lower line shows the maximum flow and temperature conditions expected. When fluid disposal is taken into account, the range of production costs which we view as most likely is between $\$ 450,000$ and $\$ 1,000,000$. The well costs in this region represent combinations of producing and reinjection wells.

For comparison purposes, the projected (1985) as-burned cost of minemouth coal is shown. Mine-mouth coal is the most likely marginal cost competition to geothemal energy at the wellhead. The marginal users are assumed to be able to locate at either energy source solely on the basis of energy supply cost. The as-burned coal cost includes the estimated cost and efficiency of the furnace and boiler. (a)

(a) Cost projections for mine-mouth coal are discussed later under "Comparative Costs of Conventional Energy Supplies." 


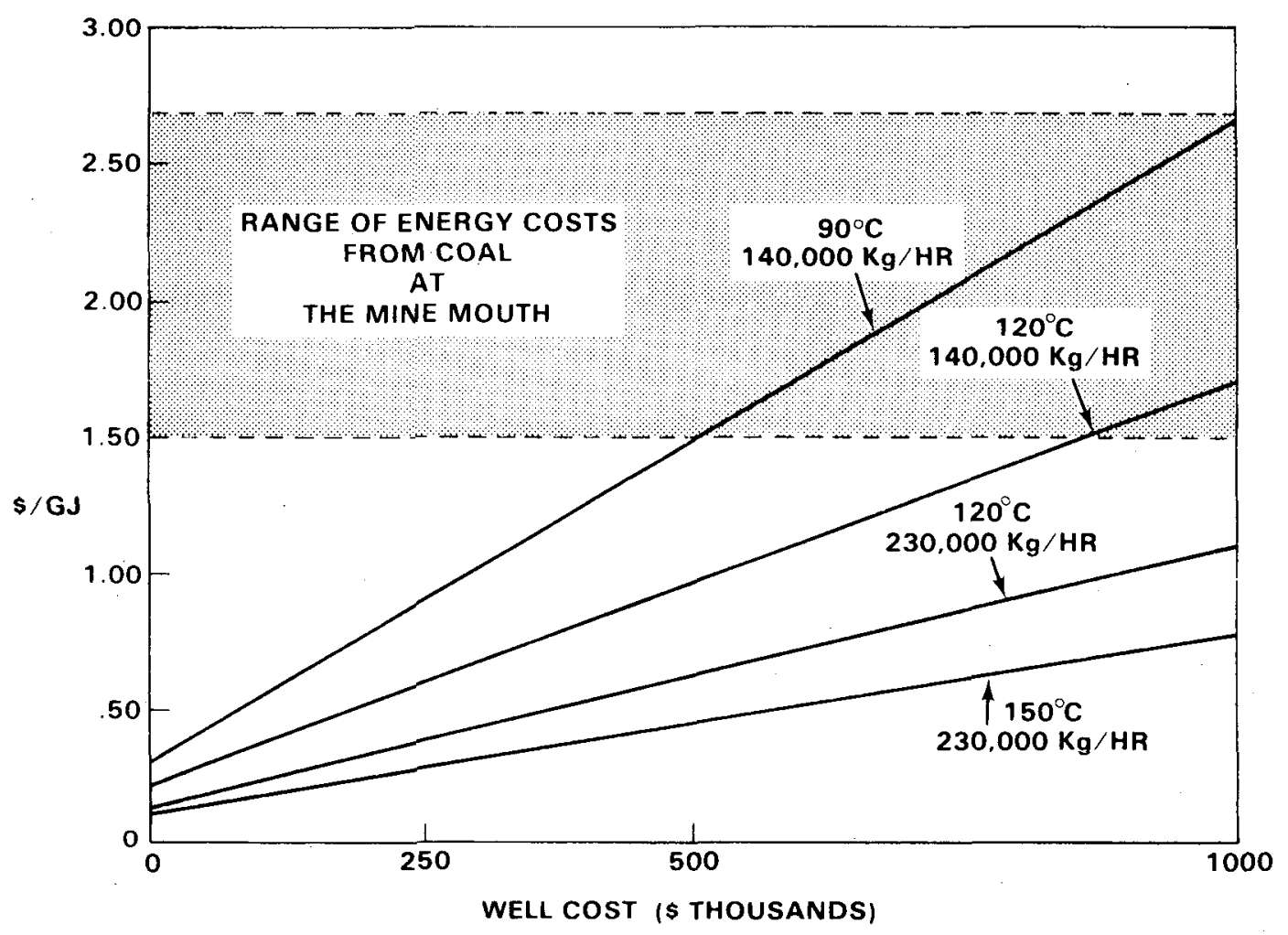

FIGURE 2. Energy Costs at the Wellhead

\section{Load Factor}

The attainment of high system load factors will be important to the economic viability of geothermal energy in most applications. Energy production costs are inversely related to the load factor. (Figure 3 ). The costs of production are predominately fixed costs. The principal variable cost will be the cost of energy consumption for pumping. The load factor is determined by the end use and is not directly controllable by the geothermal energy supplier. 


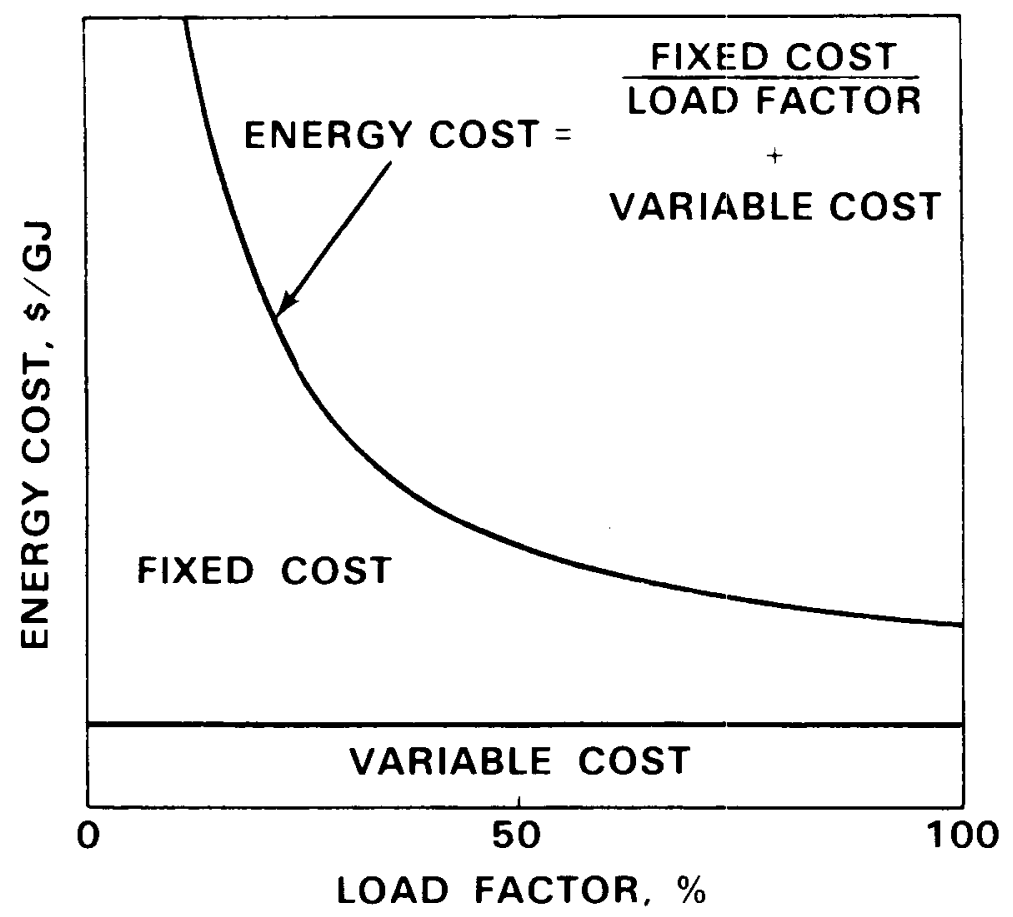

FIGURE 3. Effect of Load Factor on Cost

\section{Well Productivity and Well Cost}

Energy production costs are sensitive to temperature, well flow rate, and well cost (Figure 4). The horizontal axis in Figure 4 is a derived unit reflecting the ratio of well cost to well flow rate; energy production costs vary directly with this ratio. Well flow and well cost are interrelated and to some extent are controllable by the developer; i.e., economic tradeoffs exist between increasing production and increasing cost which the developer will seek to optimize. Costs decrease with increasing temperature as shown. Temperature, a property of the resource, is not subject to the control of the developer, except to the extent that a thermal gradient exists. 


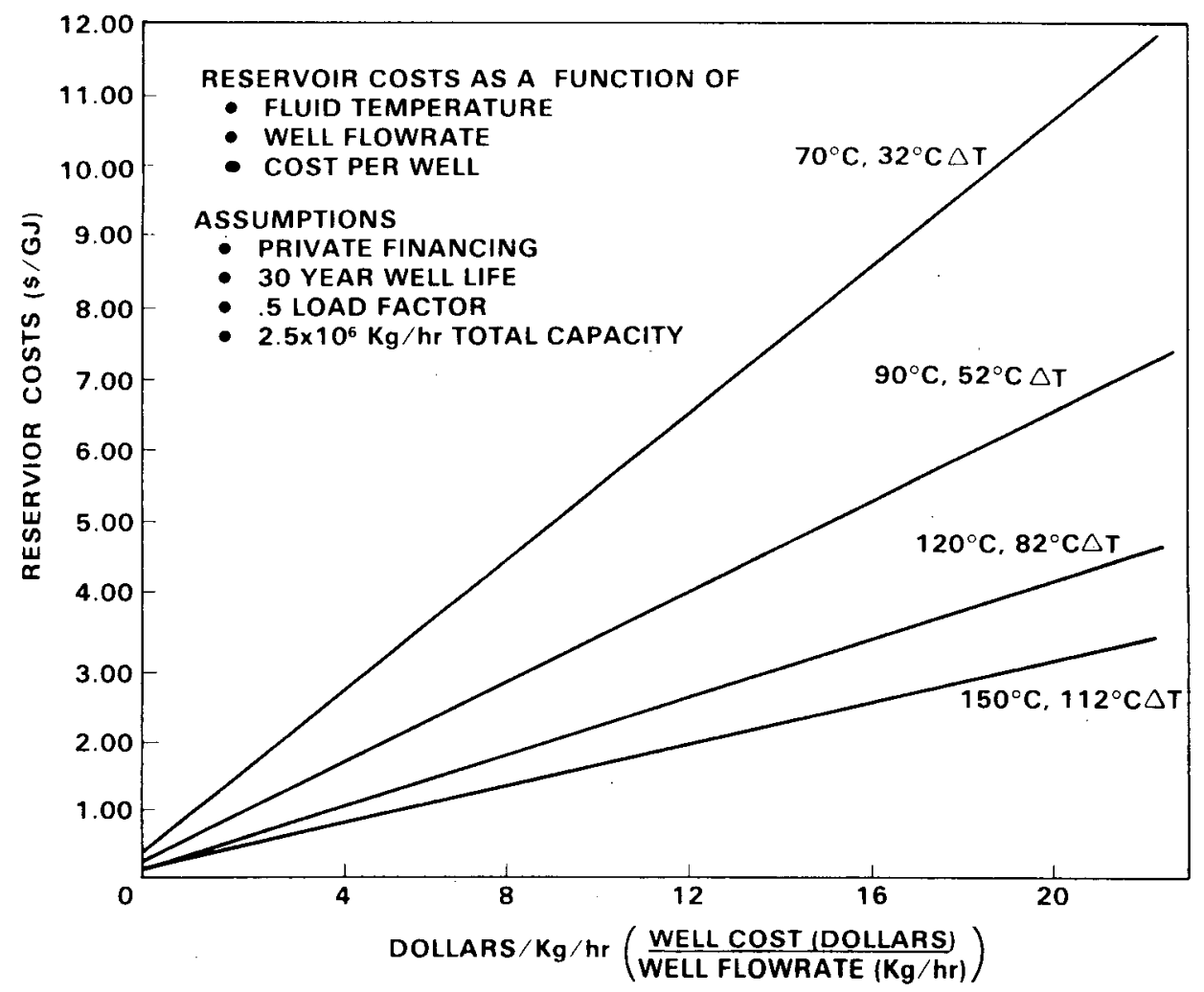

FIGURE 4. Effect of Fluid Temperature, Well Flow Rate and Vell cost on Production Costs

Well costs are mainly a function of depth. Geothermal wells currently cost on the order of $\$ 300,000 / \mathrm{km}(\$ 100 / \mathrm{ft})$. The depth to the $90^{\circ} \mathrm{C}$ to $150^{\circ} \mathrm{C}$ geothermal reservoirs is estimated by the USGS to be 1 to $1-1 / 2 \mathrm{~km}$ in most instances.

Although some existing geothermal wells have had flow rates near $450,000 \mathrm{~kg} / \mathrm{hr}$, the median flow rates are much 1ess, in the range of $140,000 \mathrm{~kg} / \mathrm{hr}$. Host geothermal wells for nonelectric uses will be pumped to obtain high flow rates without flashing. As previously stated, we have included a provision of $10 \downarrow / G J$ to cover the amortization of the pump cost and pumping power consumption. Energy production costs are inversely related to well flow rate. At a constant temperature, the energy production from a well is proportional to the flow rate. Only the energy production costs are affected by the well flow rate; the costs for fluid transmission and distribution will not be affected. As stated previously, the cost of the gathering system is included in the production costs. 


\section{We 11 Life}

Energy production costs decrease with increasing well life (Figure 5). Based on past experience, economic lifetimes should exceed 10 years and may exceed 30 years. Thus, well life should have little impact on energy production costs. Existing geothermal wells in Iceland and llew Zealand have produced from 20 to 40 years. Viell 1 ife can be controlled somewhat through varying the production rates and vell spacing.

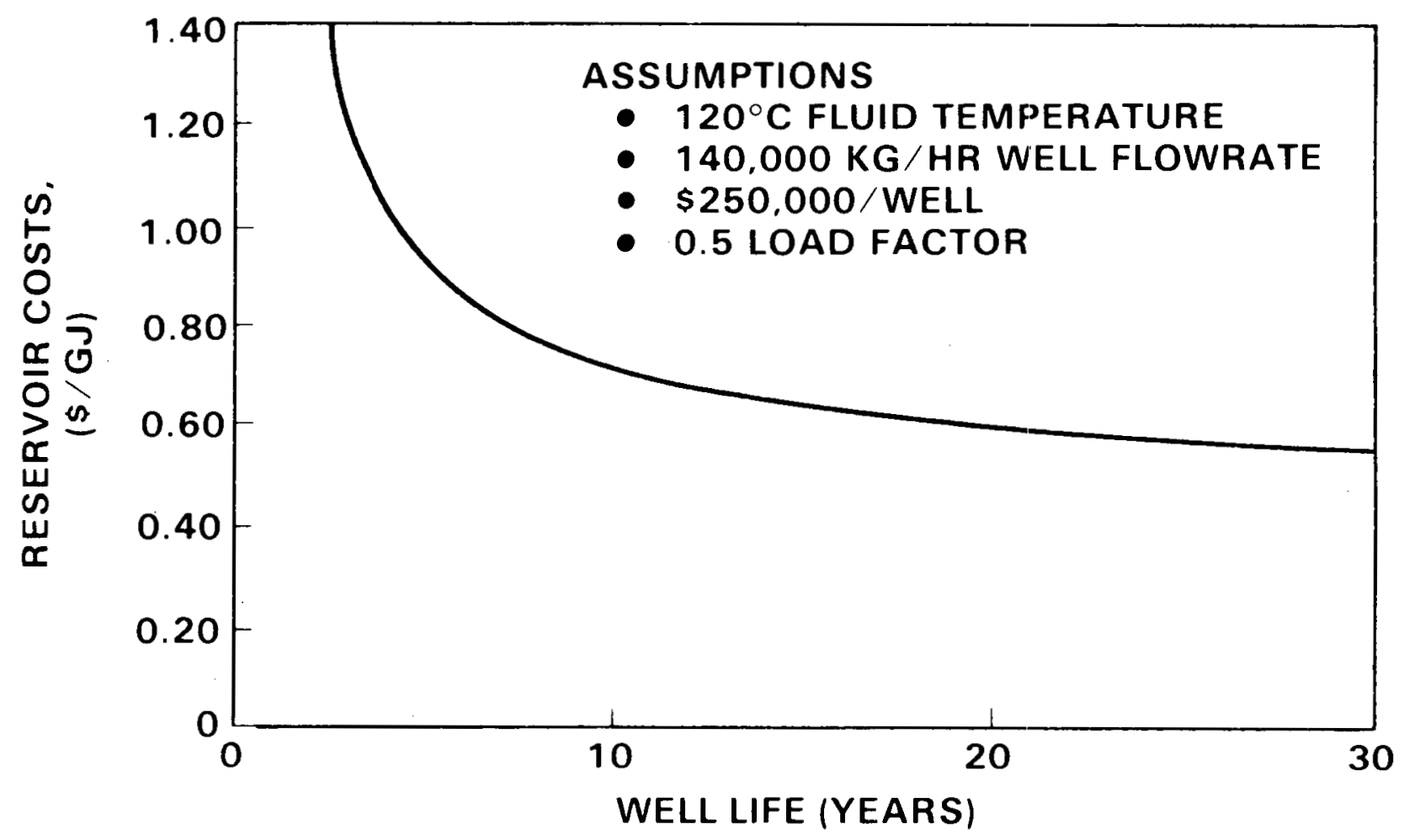

FIGURE 5. Reservoir Costs as a Function of hell Life

\section{Disposal Costs}

Disposal costs could range from negligible to in excess of the costs of brine prodiction. If the geothernal fluid is very pure, surface disposal or consumptive uses would entail low or nil costs. However, if deep reinjection were required, the cost of the reinjection wells could equal or exceed the 
cost of the production wells. The cost of disposal by reinjection depends on the same factors as the costs of brine production. In this sense, Figure 4 may also be used to estimate disposal costs by reinjection, which would be additive. We also used Figure 2 to determine the total cost of production and disposal by using the proper ratio of production to reinjection wells. For instance, a well cost of $\$ 1,000,000$ represents a pair of producing and reinjection wells at $\$ 500,000$ each, whereas a well cost of $\$ 450,000$ represents one producing well and one-half reinjection well at $\$ 300,000$ each. In this case the reinjection well is assumed to have sufficient capacity to ahsorb the flow from two producing wells.

\section{FLUID TRANSMISSION COSTS}

Fluid transmission costs are primarily related to the distance between the user and the vell. In addition, the peak demand, the average annual load factor, and the temperature of the fluid also affect the costs. The reference conditions used in our cost analyses and the expected range of values for these factors is shown in Table 4. Other factors, which are site dependent, will not be addressed in this study; these include the terrain, cost of rightof-way, and whether pipe burial is required. The costs in this section refer to transmission costs only; the costs of energy production are not included.

\section{TABLE 4. Key Transmission System Parameters}

Parameter
Temperature
Pipe Diameter
Distance
Load Factor

Flow rate and temperature have significant impacts on the cost of energy transmission (Figure 6 ). The flow rate refers to the peak demand. The peak demand is determined by the coincident end use demands. Since pipe costs increase roughly linearly with diameter while capacity increases with the square of the diameter, economies of scale are achieved with increasing peak demand. Thus, a large market would tend to he served more economically than a small one. 


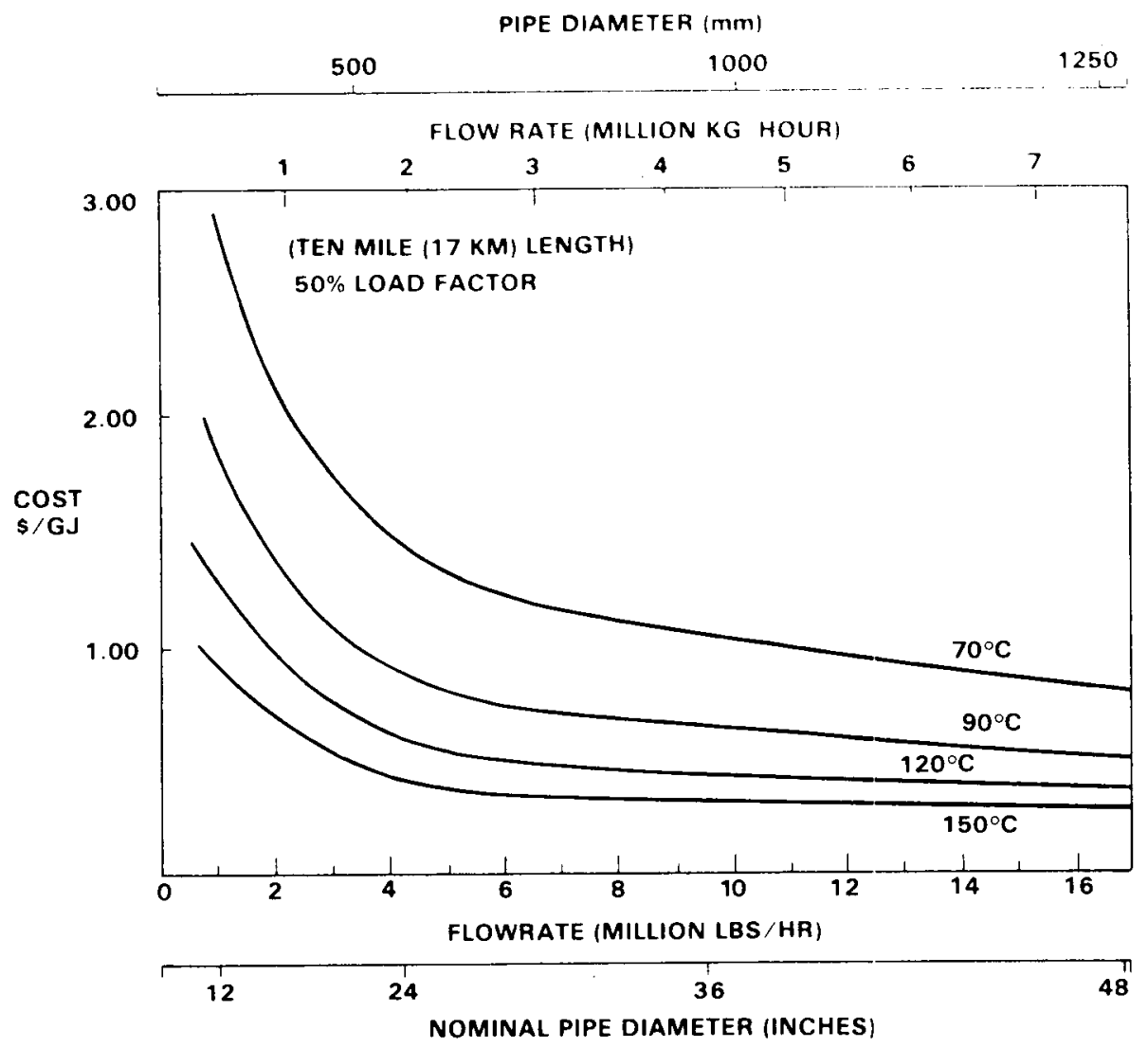

FIGURE 6. Energy Transmission costs

Transmission costs decrease wit: increasing temperature because the energy content of each pound of fluid delivered increases with temperature. At a constant pipeline capacity, transmission costs decrease linearly with temperature. At a constant energy demand, transmission costs decrease nonlinearly with temperature because the relationships between pipeline diameter, cost and capacity are nonlinear as discussed above.

As with brine production costs, the load factor also has a significant impact (Figure 3) on transmission costs. The costs for fluid transmission derive mainly from the initial investment in the pipeline. Operating expenses, including pumping and maintenance, will usually be small. Since the principal transmission costs are fixed costs, high load factors contribute signficantly to lowering the unit energy costs. 
The effect of flow rate and temperature on the capital cost of transmission lines is illustrated in Figure 7 . Schedule 10 pipe (seami-welded) with polyurethane insulation is used for temperatures below $100^{\circ} \mathrm{C}$; schedule 40 pipe (seamless) with calcium silicate insulation is used for temperatures above $100^{\circ} \mathrm{C}$. Estimated installation costs, flow rates, and energy transmission capabilities are summarized in Table 5 for several pipe diameters. The economic flow velocity used to construct this table was $1.9 \mathrm{~m} / \mathrm{sec}$.

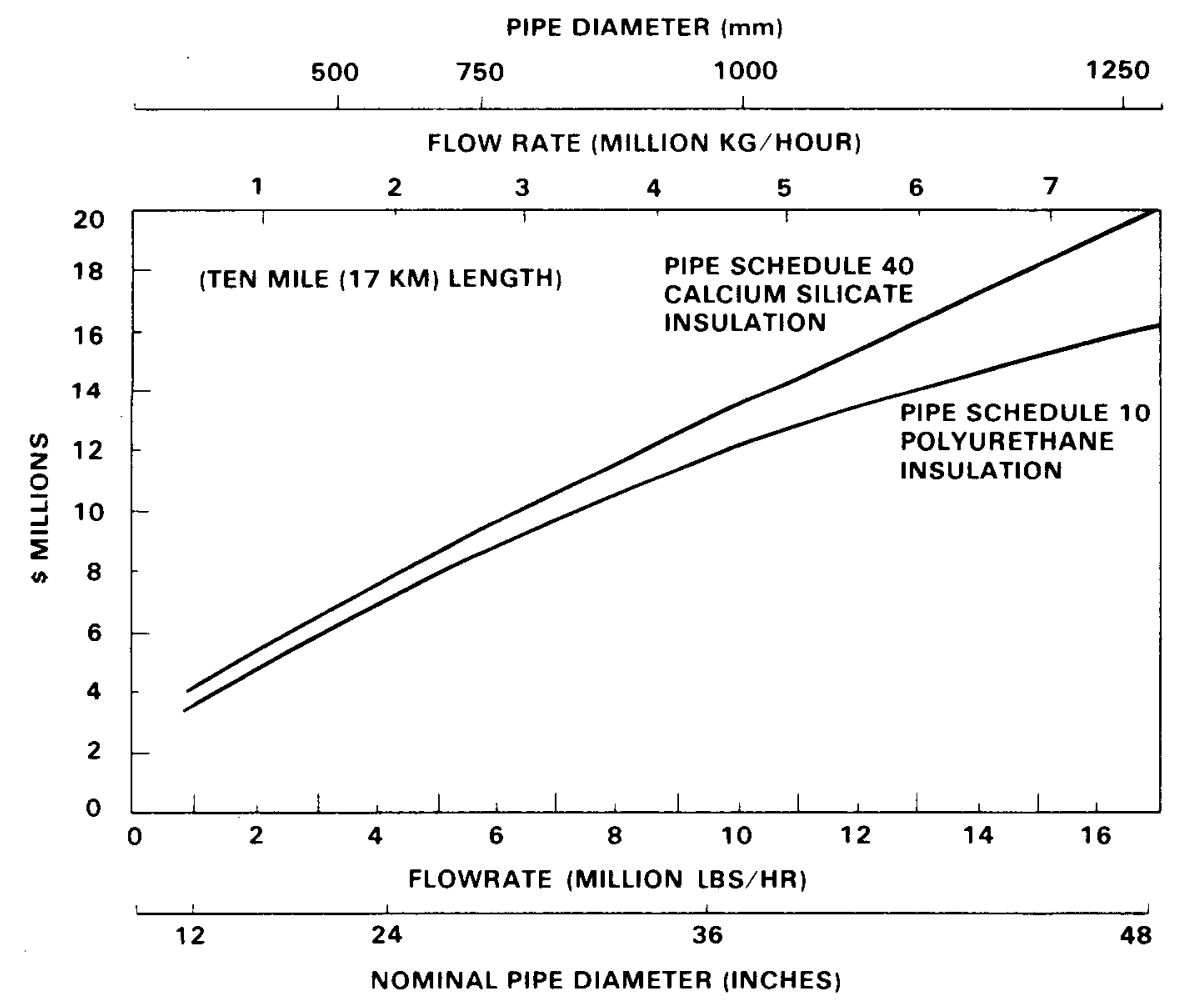

FIGURE 7. Transmission Line Capital costs

Our cost estimates are based on insulated steel pipe, which is conventionally used in these temperature ranges. New developments in pipe technology; e.g., plastic-lined, reinforced concrete, asbestos-cement, and fiberglass-epoxy, hold promise for reducing transmission costs, especially for lower-temperature water. A large program for testing new pipe designs is in progress at the Studsvik Research Center in Sweden. It is reported that "even when limiting temperatures to $100^{\circ} \mathrm{C}$, the newer pipes are calculated to give lower costs than steel pipelines of conventional design. 
TACLE 5. Transmission Systeli Design Configurations

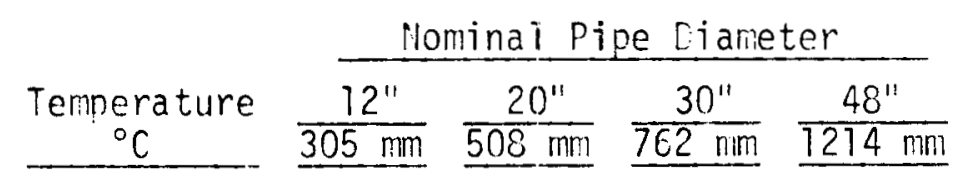

Installed Cost; $\$ / \mathrm{ft}$

Schedule 10 pipe

with potyurethane

$\begin{array}{lllll}<100 & 59 & 97 & 157 & 290\end{array}$

Schedule 40 pipe

with calcium silicate.

$>10 n$

$74 \quad 112$

178

343

Economic Flow, $\mathrm{kg} / \mathrm{sec}$

132

368

$827 \quad 2118$

Energy Transported, GJ/hr

$\begin{array}{rrrrr}70 & 70 & 19.4 & 435 & 1117 \\ 9 C & 110 & 305 & 686 & 1754 \\ 120 & 170 & 471 & 1059 & 2712 \\ 150 & 229 & 637 & 1432 & 3669\end{array}$

The distance of fluid transmission will be a limiting factor for nonelectric applications of geothermal energy. Transmission distances for existing geothermal applications are short, rarely exceeding $15 \mathrm{~km}$. Although oil and natural gas can be economically piped over thousands of miles, the economic limitation for geothermal fluids will probably be less than 100 miles because of the low energy content of the fluid. For instance, fuel oil contains on the order of 100 times more energy per unit volume than hot water. The impact of distance on transmission costs is illustrated in Figure 8 for three fluid temperatures and pipeline capacities. 


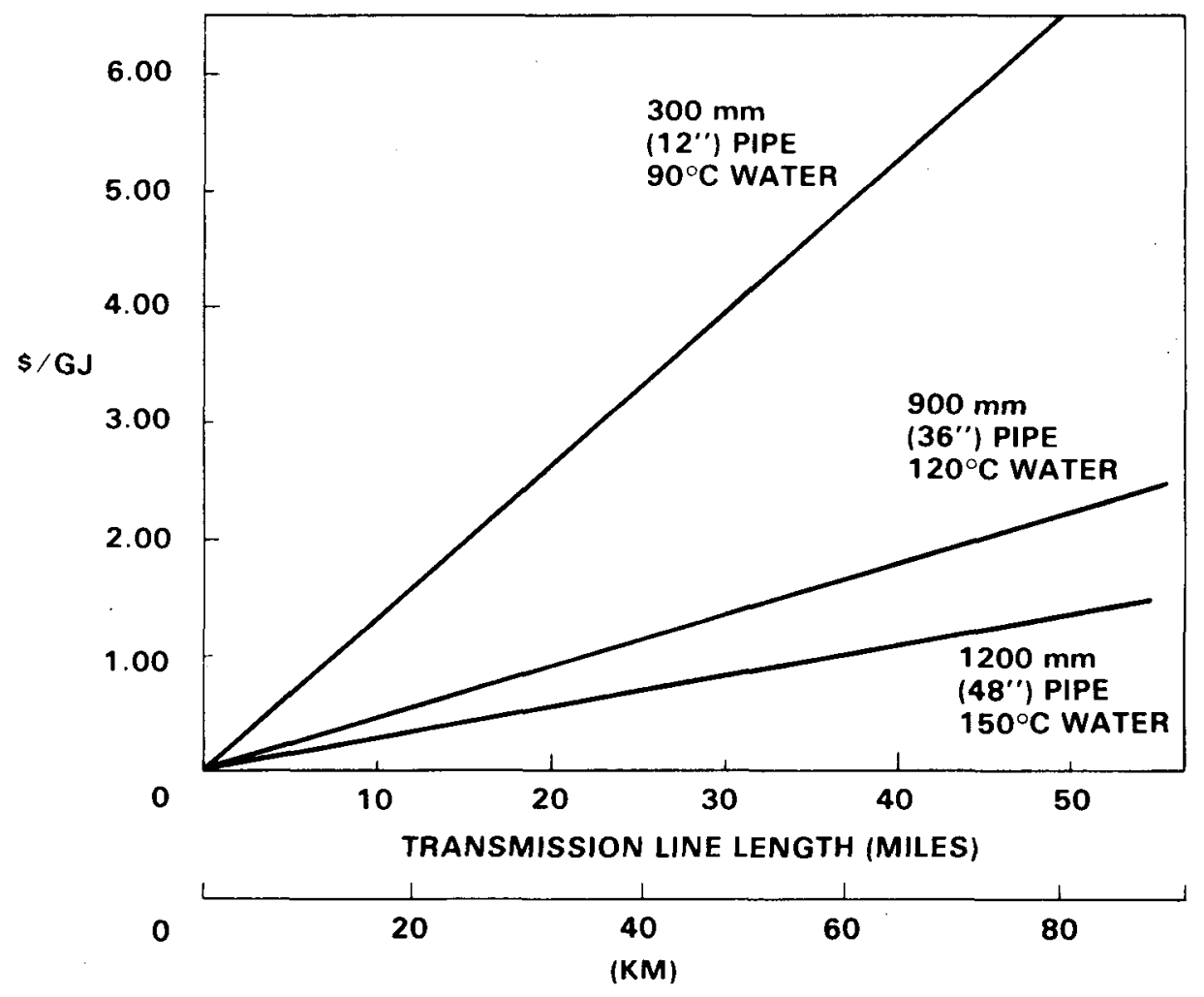

FIGURE 8. Energy Transmission Costs

\section{DISTRICT HEATING DISTRIBUTION COSTS}

The costs of district heating are dependent on many factors related to climate, community characteristics, resource conditions, financing, system design, and construction. We will examine the impact on distribution costs over the range of values (Table 6) expected for many of these factors. The costs in this section refer to the district heating distribution system only; transmission and production costs are not included. The cost of the heating system within the building is not included. The district heating costs in this report refer to new construction unless otherwise stated. 
TABLE 6. Key District Heating Parameters

\begin{tabular}{lll}
\multicolumn{1}{c}{ Parameter } & Reference Values & \multicolumn{1}{c}{ Range } \\
\cline { 3 - 4 } Fluid Temperature & $90^{\circ} \mathrm{C}$ & $70-150^{\circ} \mathrm{C}$ \\
Size (population) & 12,000 & $1,000-50,000$ \\
Climate & $3,300^{\circ} \mathrm{C}$ degree days & $1,000-8,000$ \\
Minimum Design Temperature & $-18^{\circ} \mathrm{C}$ & $-45^{\circ} \mathrm{C}$ to $0^{\circ} \mathrm{C}$ \\
Population Density & $10,000 / \mathrm{km}^{2}$ & $2,000-30,000 / \mathrm{km}^{2}$
\end{tabular}

Climate

Climate affects district heating costs through two factors - the minimum exterior temperature and the heating degree days. The minimum temperature establishes the peak load heating requirements and thus determines the size and cost of the pipes. Lower exterior temperatures require more flow and larger pipes. Larger pipes increase the capital cost of the system. For economic reasons, district heating systems are usually designed to meet less than the peak demand. The peak heating requirements are then met with supplemental heat. The impact of the exterior design temperature on the capital cost of district heating systems is shown in Figure 9.

The number of heating degree days establishes the annual energy usage. In cold maritime climates, such as Iceland, the annual eneray usage is high and relatively constant throughout the year. The average load factor on the Icelandic systems is about $50 \%$ of system capacity. In temperate climates, the average annual energy usage is less and the systems would operate at lower capacity factors. Since district heating systems are very capital intensive, reductions in system capacity utilization, as reflected by degree days, lead directly to higher energy costs (Figure 10).

In some Icelandic systems, the energy is priced on a peak demand basis rather than on an energy consumption basis. In these systems, flow-limiting valves replace meters. This eliminates the cost of meters and expenses for meter reading. However, since this system would run the risk of profligate energy consumption in off-peak periods, it would be suitable only in situations in which excess energy is available and conservation of off-peak energy is not important. These situations will probably be rare in the U.S. 


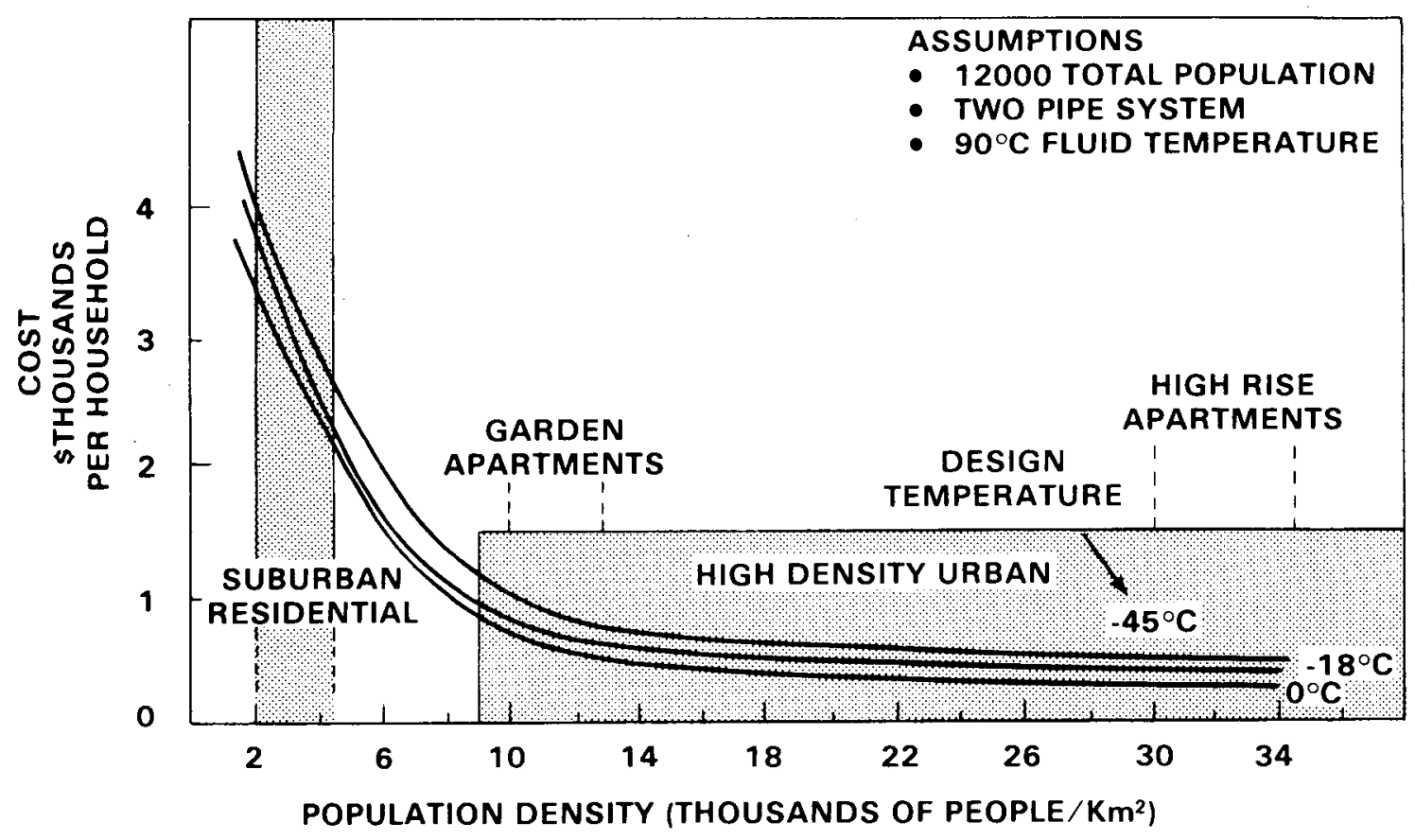

FIGURE 9. Capital Costs for District Heating Distribution System

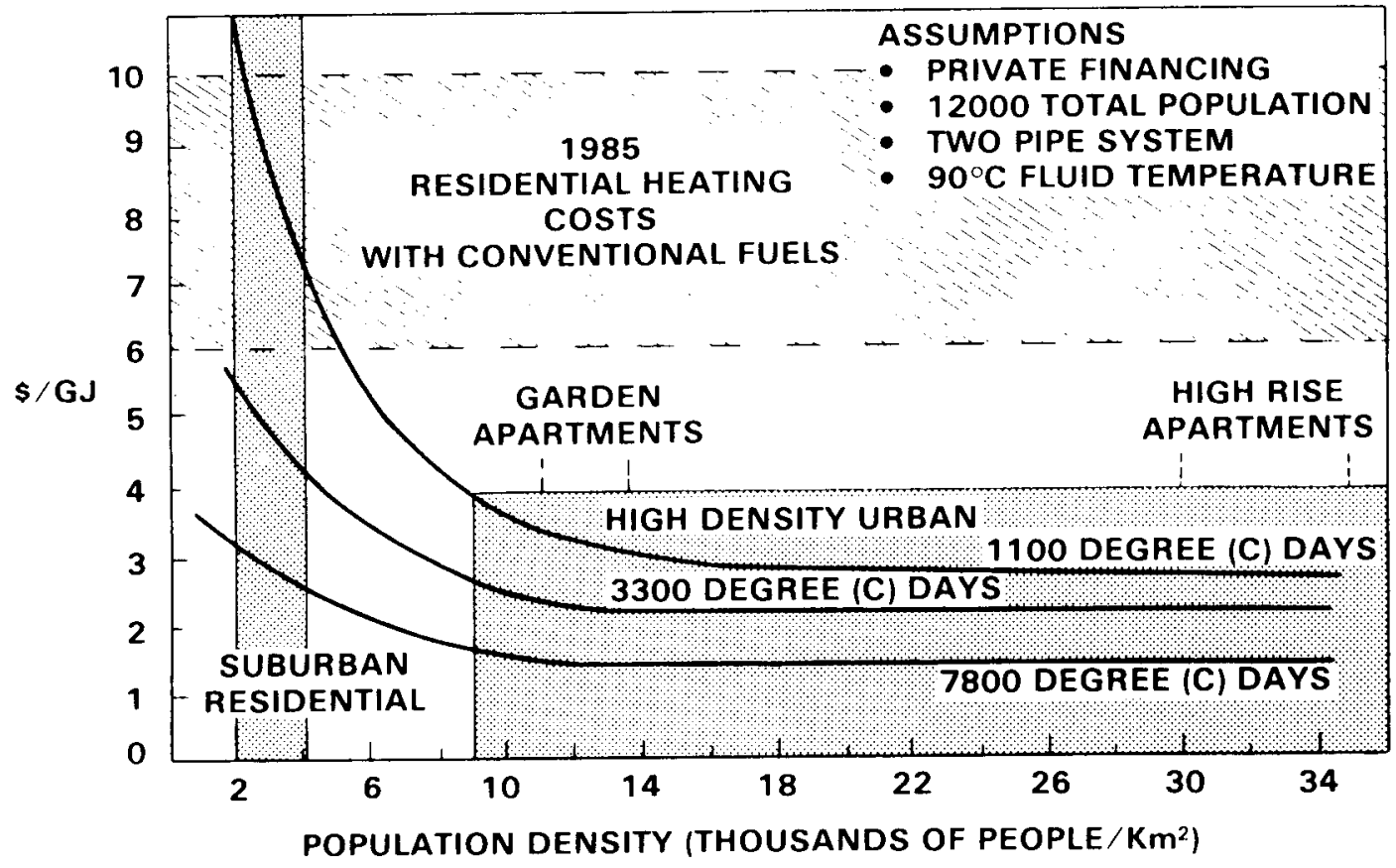

FIGURE 10. Energy Distribution Costs 


\section{Community Characteristics}

\section{Population}

The total population of the district influences district heating costs in three ways. First, with increasing population economies of scale are realized in the piping for the distribution network (Figure 11). Pipe weight and costs increase nearly linearly with diameter, while flow capacity increases with the square of the diameter. A minimum district size of 1000 dwelling units will probably be required for economic feasibility. Second, increasing population reduces costs associated with the investment in wells up to the point at which the maximum vell flow is fully utilized. This population, or multiples of this population, tend to yield local minimum cost points. Fiqure 11 dces not illustrate this point since it refers to distribution system costs only and does not include the costs of the energy supply. Third, with increasing population economies of scale are realized in the transmission piping as discussed previously.

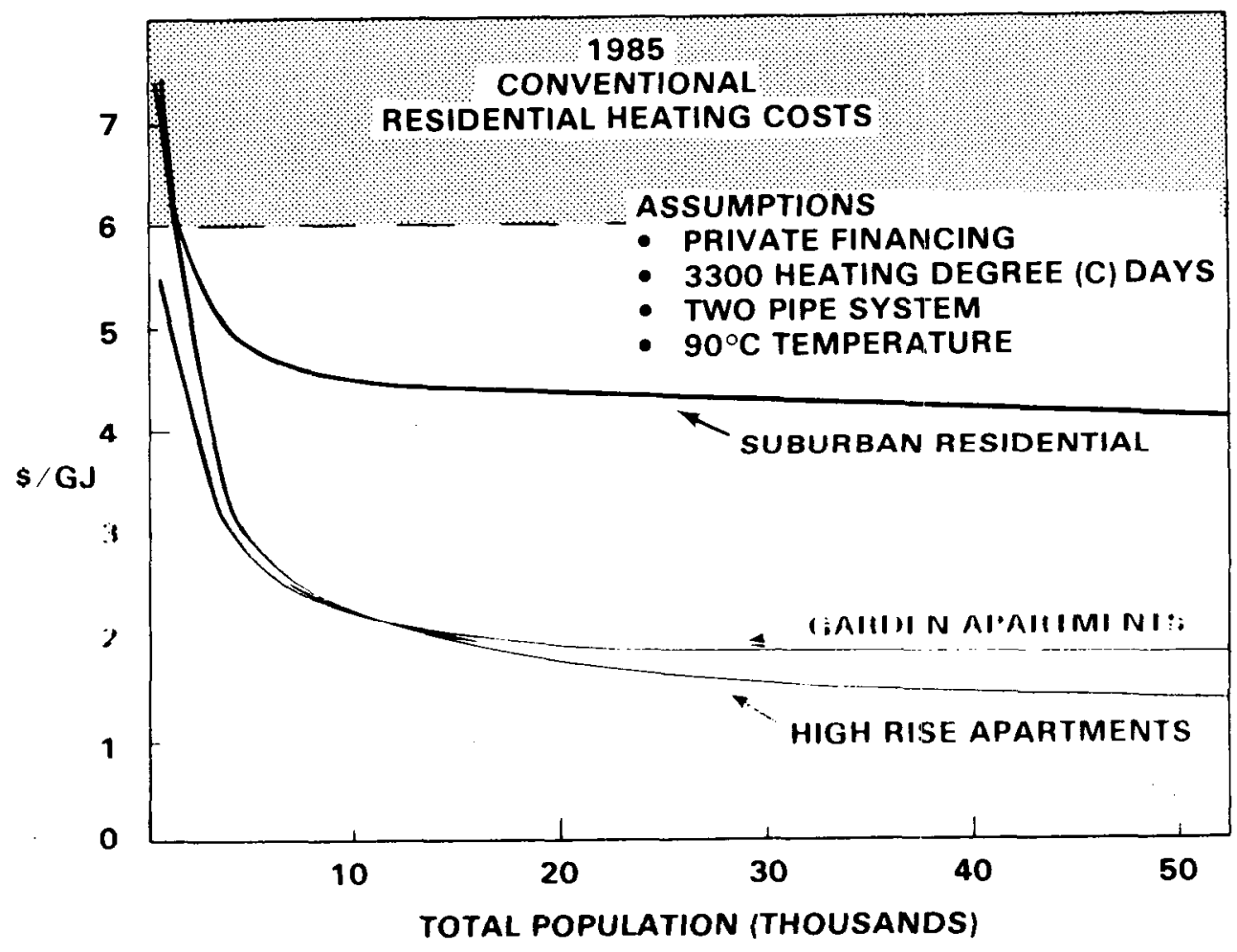

FIGURE 11. Energy Distribution Costs 


\section{Population Density}

Population density is one of the most important factors affecting district heating costs, as previously shown in Figures 9 through 11. Increasing population density reduces district heating costs through reducing the average length of pipe run. With very high population densities, resulting from large multi-story apartment buildings, economies of scale are realized in the distribution system through the use of larger diameter pipe. This cost advantage might be partially offset, however, by higher costs for heat distribution within the apartment buildings. Uur cost analyses do not include costs of the heating systems within the buildings, since heating is but one of the design considerations of the building architects.

\section{New Construction}

District heating will be more economically attractive for new housing developments than for established areas. Routing of the water distribution lines will be more direct and construction less impeded than in established areas, leading to lower costs. The initial installed costs for both hot water heating systems and conventional heating systems within homes and commercial buildings are expected, on the average, to be nearly equal. District heating systems and conventional heating systems then should compete for new construction projects on the basis of projected energy supply costs and reliability.

\section{Established Areas}

The cost of installing district heating systems in established residential and commercial areas will generally be higher than in new developments. Trenching costs will be higher because existing streets and sidewalks must be dug up and replaced. Indirect routing of district heating lines around existing sewer and water lines will also increase installation costs. Based on limited data from Iceland, construction costs for district heating systems in established areas will be 10 to $30 \%$ higher than costs in new areas. 
The retrofitting cost for replacing existing heating systems in residential and commercial buildings with hot water heating systems will be a deterrent to district heating in many established areas. Retrofitting is estimated to cost $\$ 500$ to $\$ 2000$ per dwelling unit. The lower part of the cost range would apply to the conversion of an existing forced air or hot water system.

The Locid Duration Curve

In the preceding sections the costs for energy production, transmission, distribution, and disposal we:re treated separately. The total cost for district heating is the sum of these four costs. These costs have similar characteristics. They are capital intensive. Fixed costs dominate. Variable costs are negligible. The system load factor has an enormous impact on the average cost of energy.

A typical load duration curve for a district heating system is illustrated in Figure 12. The base load is the year-around sanitary water demand. The shape of the seasonal heating demand is affected by the climate. The peak demand tends to be more exaggerated in inland climates than in coastal locations.

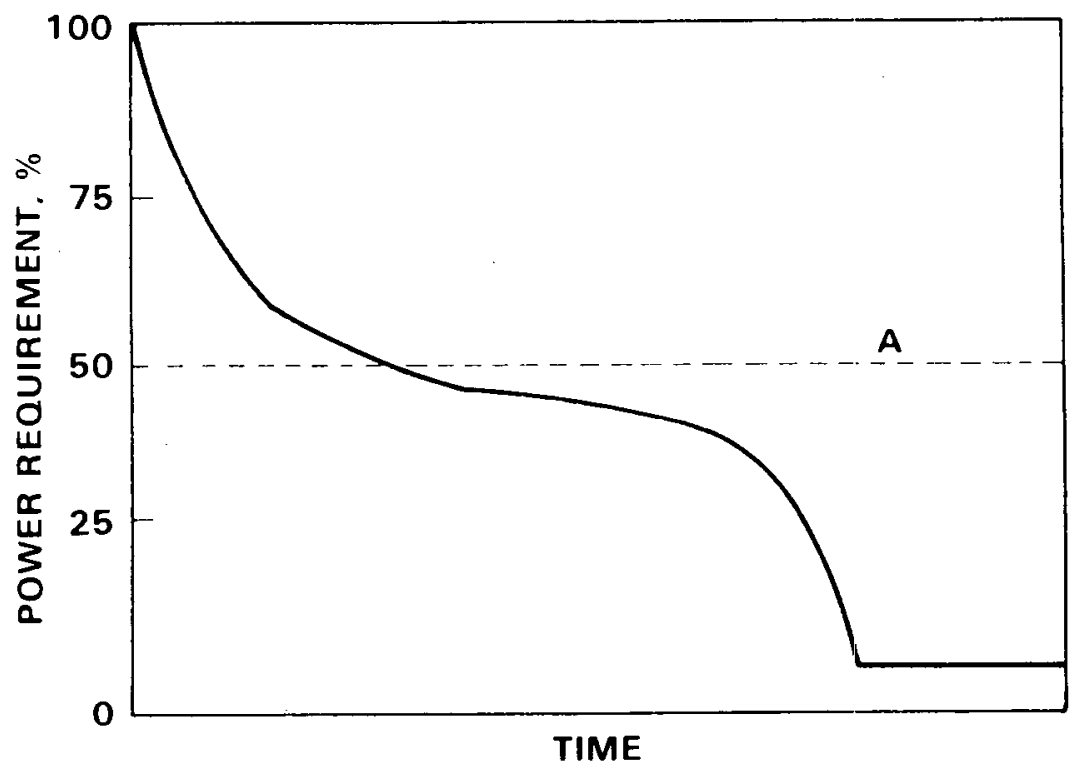

FIGURE 12. Load Duration Curve 
The utilization of energy storage capacity and supplemental energy to meet peak demands provides an opportunity for system optimization. The average load factor for the distribution system is equal to the area under the load duration curve divided by the maximum potential energy distribution for the year. The geothermal energy costs related to production and transmission might be reduced by designing the geothermal transmission and production capacity to meet less than the peak demand; for instance, at level $A$ in Figure 12. In this way the load factor on the geothermal transmission and production systems can be substantially increased. The excess demand, above $A$, must then be met from energy storage and supplemental heat. Energy storage and supplemental heating also have variable costs and fixed costs related to capacity. The load factors on the energy storage facilities and supplemental heating equipment, which are installed to meet only the peak demand, will be low. Through classic system optimization techniques, a minimum cost system can be designed which employs the optimal geothermal, storage, and supplemental heating capacities. We have not sought to achieve this optimization in this study.

For this analysis we have assumed that the geothermal district heating system supplies $90 \%$ to $95 \%$ of the annual heat load demand. The remaining $5 \%$ to $10 \%$ of the demand is assumed to be met with supplemental heat. The supplemental heat is fuel oil at $\$ 6 / 0 \mathrm{~J}$. We have not included any geothermal energy storage capacity.

\section{PROCESS HEAT RETROFITTING AND UTILIZATION}

In addition to the costs for production, transmission, and disposal for geothermal process heating applications, some retrofitting costs may be incurred. These might include heat exchangers and other equipment for converting the conventional system to geothermal energy. For processes in which water is normally used to carry heat, few or no retrofitting costs are anticipated. For other processes, such as drying with hot air, the use of geothermal energy may require adding water-to-air heat exchangers. The economic incentive for converting to geothermal energy vill depend on both the cost of the energy supply and the in-plant retrofitting costs: 
One of the principal retrofitting-cost items is likely to be a heat exchanger. To determine the magnitude of retrofitting costs, we calculated heat exchanger costs for two process heating demands and at two load factors. The cost of a heat exchanger is a function of the surface area available for heat transfer. Table 7 shows the heat transfer areas and capital costs for she 11 -and-tuke exchangers for $9.5 \mathrm{Gl} / \mathrm{hr}$ and $190 \mathrm{GJ} / \mathrm{hr}$ demands at load factors of 0.5 and 1.0 . The capital costs (in July 1976 dollars) were calculated by the GEOCITY niodel based on a gectherrial hrine inlet temperature of $150^{\circ} \mathrm{C}$ and a reject temperature of $100^{\circ} \mathrm{C}$. To compute the equivalent energy costs, we used an equivalent annual fixed charge rate of $15 \%$. The equivalent energy costs are low, ranging from $\$ 0.05 / \mathrm{GJ}$ for a $190 \mathrm{GJ} / \mathrm{hr}$ demand at a load factor of 1.0 , to $\$ 0.19 / \mathrm{GJ}$ for a $9.5 \mathrm{GJ} / \mathrm{hr}$ demand at a load factor of 0.5 . Because we expect retrofitting costs to be small and to vary with specific applications, we have not included them in our anaiyses.

TABLE 7. Shell-and-Tube Heat Exchanger Costs

\begin{tabular}{|c|c|c|c|c|}
\hline & $\begin{array}{c}\text { Case } \\
1 \\
\end{array}$ & $\begin{array}{c}\text { Case } \\
2 \\
\end{array}$ & $\begin{array}{c}\text { Case } \\
3 \\
\end{array}$ & $\begin{array}{c}\text { Case } \\
4 \\
\end{array}$ \\
\hline Heating Demand, GJ/hr & 9.5 & 9.5 & 190 & 190 \\
\hline Load Factor & 0.5 & 1.0 & 0.5 & 1.0 \\
\hline Heat Transfer Area, $\mathrm{ft}^{2}$ & 3,250 & 3,250 & 64,900 & 64,900 \\
\hline Initial Capital Cost, $\$ 10^{3}$ & 51 & 51 & 529 & 529 \\
\hline Operating cost, $\$ 10^{3} / \mathrm{yr}$ & 1 & 1 & 11 & 11 \\
\hline Equivalent Energy Cost, $\$ / G J$ & 0.19 & 0.09 & 0.10 & 0.05 \\
\hline
\end{tabular}

The process itself will have a significant impact on the costs of the geothermal energy supply through the size of the energy demand, the maximum temperature of utilization, the effective temperature range $(\Delta T)$ of utilization, and the impacts of seasonal factors and plant operating schedule on the load factor. These factors have already been treated for the production, transmission, and disposal costs. 
For district heating applications, the geothermal brine is rejected at $33^{\circ} \mathrm{C}$. For process heating applications, the reject temperature is $100^{\circ} \mathrm{C}$. The effect of the higher reject temperature on the production and transmission costs is shown in Figure 13. The costs increase as the minimum temperature of utilization increases because less of the available energy in the brine is being utilized.

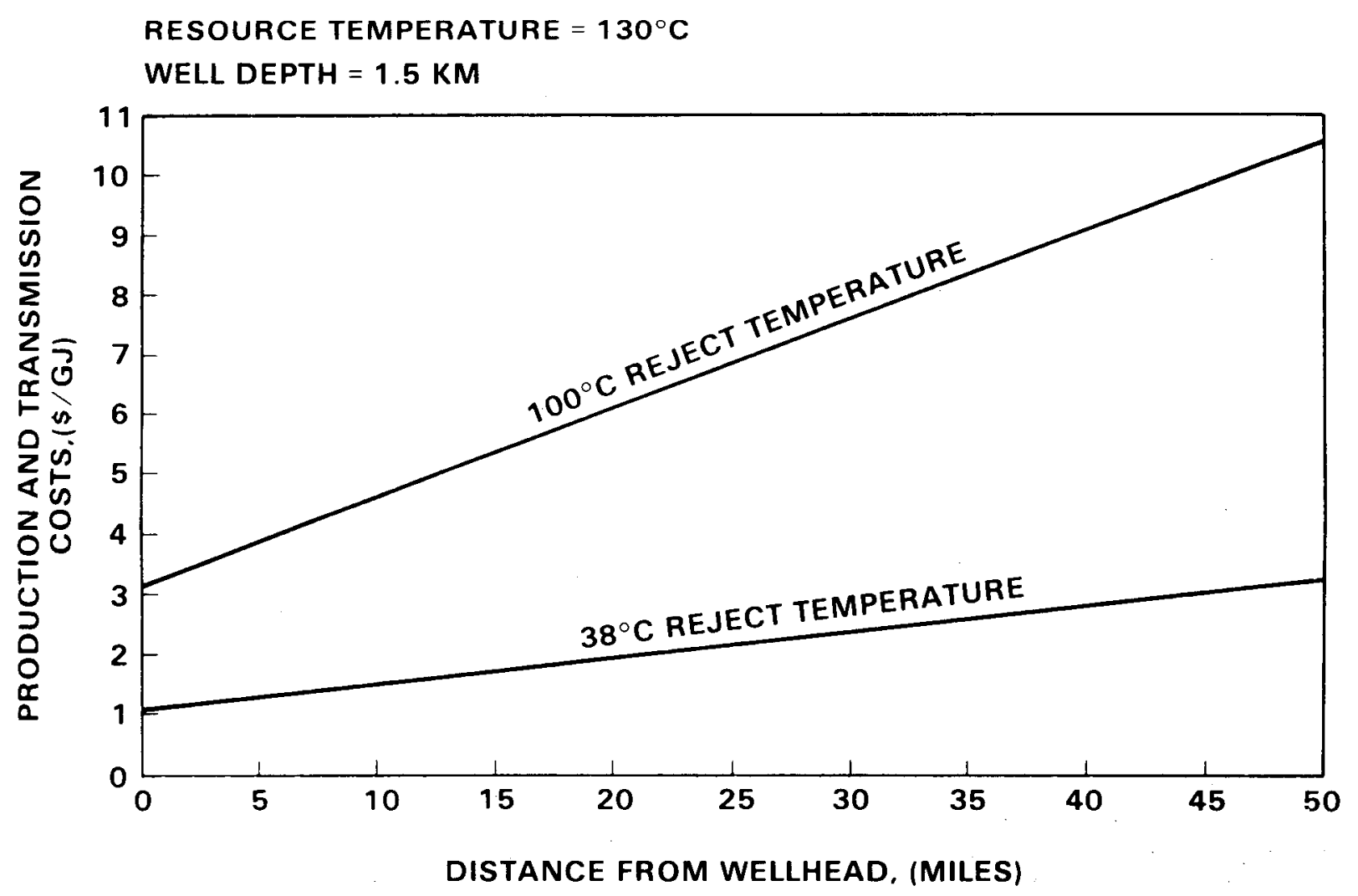

FIGURE 13. Production and Transmission costs as a Function of Reject Temperature 
Prices for conventional fuels are projected to increase in real dollars through 1985 (Table 8). The proiections, based on FEA data, assume continuation of price controls on interstate natural gas. These estimates are national averages, but with the exception of electricity, prices are also representative of prices in the western U.S. Electricity prices in the lest, in particular the llorthwest, are lower because of the low-cost hydroelectric power base. Coal prices are highly variable in the West, being dependent on the source, transportation costs, and whether pricing is based on long-term contract or the spot market.

\section{TABLE 8. Energy Prices for Conventional Fuels}

\begin{tabular}{|c|c|c|c|c|}
\hline & $\begin{array}{l}1975^{(a)} \\
\text { Price } \\
\end{array}$ & $\begin{array}{l}1985^{(b)} \\
\text { Price } \\
\end{array}$ & 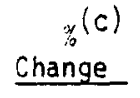 & $\begin{array}{l}\text { Recent } \\
\text { Prices }(d)\end{array}$ \\
\hline \multicolumn{5}{|l|}{ Natural Gás } \\
\hline Residentiai (\$/mcf) & $1.55^{(\mathrm{e})}$ & $2.88^{(b)}$ & +86 & $2.20^{(f)}$ \\
\hline Industrial (\$/mef) & $0.73^{(e)}$ & $(g)$ & & $1.13^{(h)}$ \\
\hline Residential Heating Oil (\$/gal) & $0.38^{(e)}$ & $0.55^{(b)}$ & +47 & $0.45^{(i)}$ \\
\hline Electricity (\$/kwh) & $.027^{(c)}$ & $.034^{(c)}$ & +27 & \\
\hline Steam Coal ( $\$ /$ ton $)$ & $19.30^{(c)}$ & $37.07^{(c)}$ & +92 & $21.56^{(j)}$ \\
\hline \multicolumn{5}{|l|}{ (a) National averages } \\
\hline \multicolumn{5}{|c|}{$\begin{array}{l}\text { (b) Federal Energy Administration, draft of National Energy Outlook, Table IV-24, } \\
\text { reported in Energy User News, } 2(11) \text {, p. 1, March } 2,1977 \text {, in constant } 1975 \\
\text { dollars. The percentage change in the FEA price projections for each energy } \\
\text { category for the reference scenario were added to the } 1975 \text { base price to } \\
\text { obtain the } 1985 \text { price. }\end{array}$} \\
\hline \multicolumn{5}{|l|}{ (c) ibid. } \\
\hline \multicolumn{5}{|l|}{ (d) Current dollars } \\
\hline \multicolumn{5}{|c|}{ (e) Federal Energy Administration, Monthly Energy Review, May 1977.} \\
\hline \multicolumn{5}{|l|}{ (f) March, 1977} \\
\hline \multicolumn{5}{|c|}{$\begin{array}{l}\text { (g) If available, prices should approach residential prices more closely than at present } \\
\text { (h) November, } 1976\end{array}$} \\
\hline \multicolumn{5}{|l|}{ (i) February, 1977} \\
\hline \multicolumn{5}{|c|}{ (j) November, 1976, Spot coal delivered to utilities. } \\
\hline
\end{tabular}


Space heating is commonly provided by natural gas, fuel oil, or electricity. Energy costs for residential heating are projected to increase in real dollars (Table 9), which will provide opportunities with time for the economic substitution of geothermal district heating. The energy costs include the energy utilization efficiency. The average energy utilization efficiencies for residential heating are: gas furnace - $69 \%$, oil furnace $66 \%$, and electric furnace - $95 \% .(5)$ The residential electric heating costs reflect national average prices as stated above.

\section{TAELE 2. Energy Costs for Residential Heating (In
1975 Dollars) (\$/GJ of Space Heat Delivered)}

$\begin{array}{lrr} & \frac{1975}{2.09} & \underline{1985} \\ \text { Hatura7 Gas } & 3.09 & 3.89 \\ \text { Heating Oi1 } & 3.93 & 5.78 \\ \text { Electric Furnace } & 7.90 & 10.03\end{array}$

(a) Includes utilization efficiency of fuel in the furnace.

However, in 1985 the marginal cost for electricity from new therma 1 and nuclear generating facilities is likely to be much higher than the average cost, even in the West. For instance, the current marginal cost for service is $3.5 \mathrm{c} / \mathrm{kWh}$ for the Portland General Electric Co. while the current average cost is $26 / k$ wh. (6) Similarly, the marginal cost for new natural gas will be much higher than the average cost. In 1985, the narginal cost of heating oil will probably continue to be set by the cost of imported oil. Thus, the marginal costs for residential heating in 1985 (in 1975 doliars) are likely to range from a minimum of $\$ 6 / G J$ for ail to well over $\$ 10 / G \mathrm{~J}$ for electricity. When evaluating alternative energy sources, the marginal cost provides a more appropriate basis for comparison than the average cost.

Process heating is currently provided by natural gas and fuel oil. However, the availability of these fuels, narticularly natural gas, for industrial process heat is subject to curtailment. 
In the future, coal should provide the narginal cost competition for both process heating and district heating applicatiors. Projected prices for coal are shown in Table 10. Hine-mouth coal should provide the nrice comnetition to wellhead geothermal energy for industries which have energyprice mobility. Transported coal should provide price competition to geothermal energy at any location* The transportation cost of coal is related to distance and volume; ${ }^{(7,8)}$ runing $5-10$ mills/ton-mile for long hal:?s in 1974. Trarsportation rates in constant dollars have been increasing at the rate of $3 \%$ year. (9). If this trend continues, coal transportation costs in 1985 would run 7-14 mills/ton-mile. At this rate coal transportation costs would te in the range of $\$ .35$ to $\$ .70 / C_{0}$ for a 1000 mile shipment.

TABLE 10. 1985 Projected Coal Prices (In Constant 1975 Dortars)

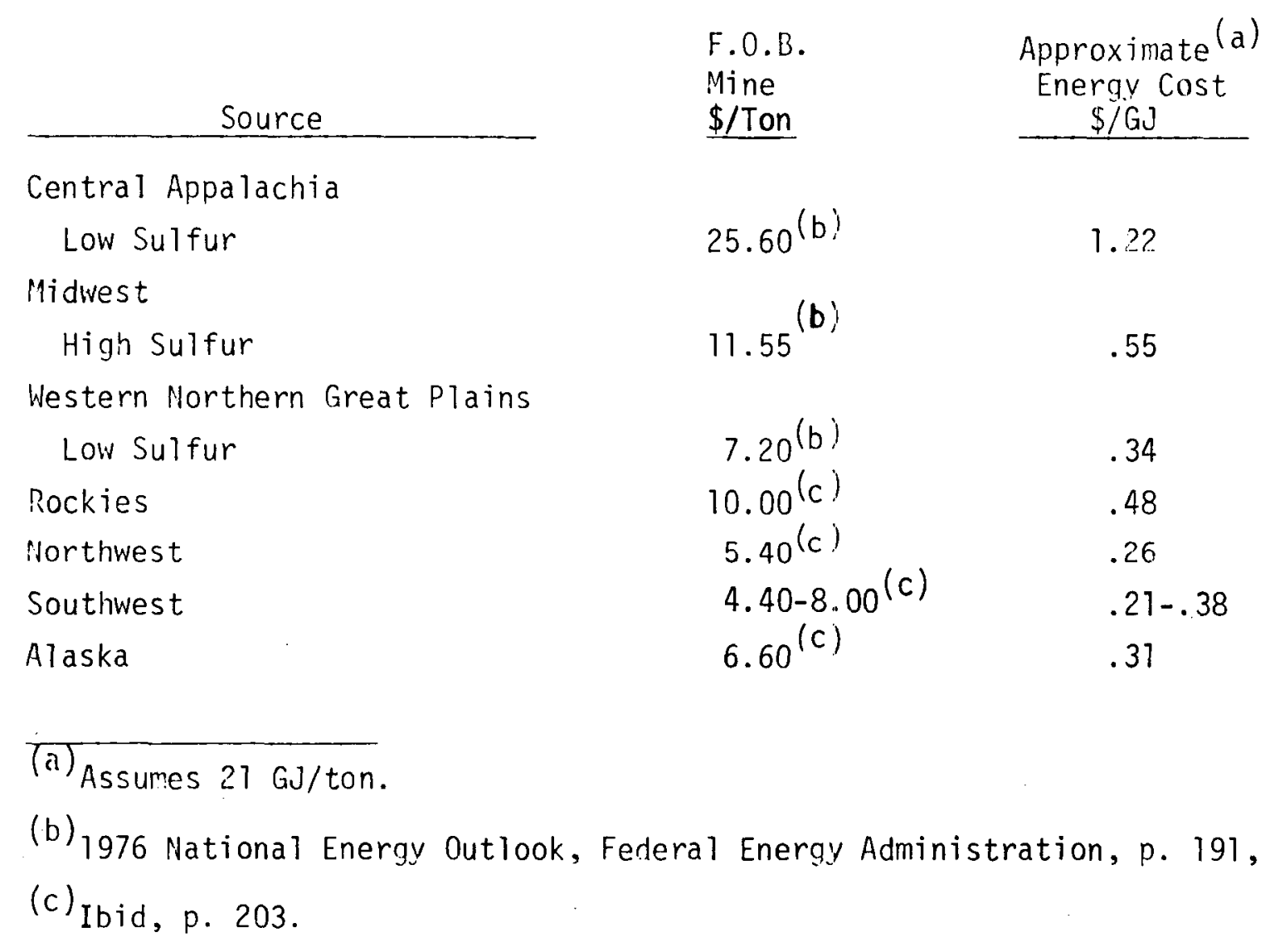

*It is assumed that the coal is transported to the site of usage of hot water. 
The use of coal for process heat, in the form of hot water, requires coal-handling facilities, a furnace, a boiler, and auxiliary equipment. Depending on the installation size and the load factor, the equivalent energy costs related to the capital investment for coal burning will run from $\$ .25 / G J$ to $\$ .93 / G$, with the most likely values being in the upper part of the range (Appendix $A$ ). Combining the capital cost with the mining and transportation costs and the combustion efficiency, process heat from coal should cost $\$ 2$ to $\$ 3 / G J$ in 1985 (in 1975 dollars). This is a very low cost compared with projections of the cost of $0 i 1$ and natural gas. These costs are based on extrapolation of the current costs of coal production, transportation, and utilization. The underlying assumption is that coal supplies are abundant and, therefore, coal prices will be relatively insensitive to other energy prices and will be determined priniarily by the costs of production.

\section{POTENTIAL GEOTHERHAL ENERGY SUPPLY}

The USGS identified 224 hot-water convection systems with temperatures from $90^{\circ} \mathrm{C}$ to $150^{\circ} \mathrm{C}$ (Table 11 ). These systems are located primarily west of the continental divide and include Alaska and Hawaii (Figure 14). The total heat content of these systems was estimated at $345 \times 10^{18}$ calories. However, one system, Bruneau-Grandview in Idaho, accounted for $76 \%$ of the heat content, and the Klamath Falls system accounted for another 9\%. The remaining 222 systems comprised only $15 \%$ of the total heat content (Figure 15).

\section{SUPPLY CURVES FOR SPACE HEATING}

We developed estimates of annual energy production potential for space heating (Table 12); this production has the energy equivalent of 1.7 billion barrels of crucle oil per year. The esimates assume $25 \%$ recovery of the stored heat at the surface and a 30-year production period. The USGS estimated the heat content above $15^{\circ} \mathrm{C}$. For space heating only the heat above $38^{\circ} \mathrm{C}$ is usable (without heat pumps). We reduced the USGS energy estimates to this $38^{\circ} \mathrm{C}$ base. 
TAELE 11: Hot Water Convection Systems From $00^{\circ} \mathrm{C}$ to $150^{\circ} \mathrm{C}$

\begin{tabular}{|c|c|c|c|}
\hline $\begin{array}{c}\text { Temperature } \\
\text { Range } \\
\text { =c } \\
\end{array}$ & $\begin{array}{l}\text { Desth } \\
\mathrm{km}\end{array}$ & $\begin{array}{l}\text { Number } \\
\text { of } \\
\text { systems }\end{array}$ & $\begin{array}{c}\text { Energy a) } \\
\text { bonter: } \\
\text { lolscalories }\end{array}$ \\
\hline $100-119$ & 1.0 & 2 & 0.9 \\
\hline $100-119$ & 1.5 & 32 & 4.2 \\
\hline $100-119$ & 2.3 & 1 & 0.2 \\
\hline $120-139$ & 0.5 & 2 & 1.0 \\
\hline $120-139$ & 1.0 & 6 & 32.5 \\
\hline $120-139$ & 1.5 & 93 & 18.7 \\
\hline $140-150$ & 1.0 & 5 & 5.8 \\
\hline $140-150$ & $i .5$ & 83 & 282.3 \\
\hline TOTAL & & $\overline{224}$ & $\overline{345.6}$ \\
\hline
\end{tabular}

(a) Above $15^{\circ} \mathrm{C}$.

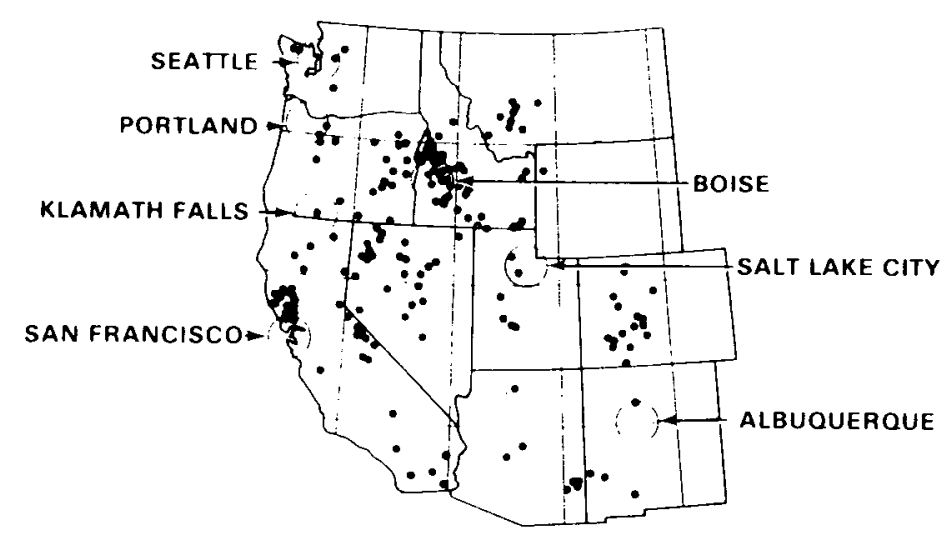

FIGURE 14. Location of Geothermal Resources in the $90^{\circ} \mathrm{C}$ to $150^{\circ} \mathrm{C}$ Range

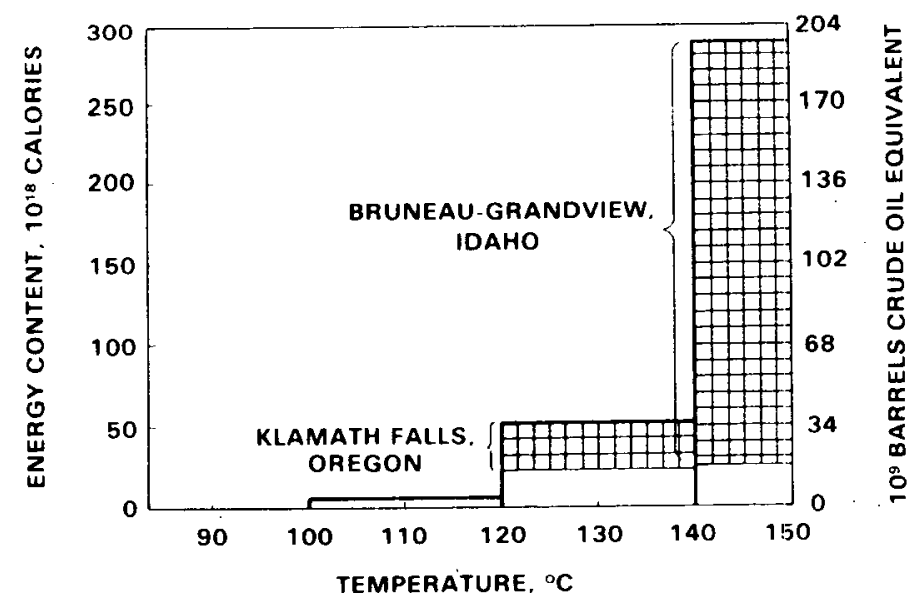

FIGURE 15. Potential Supply of Geothermal Energy in the $90^{\circ} \mathrm{C}$ to $150^{\circ} \mathrm{C}$ Range 
TABLE 12 Potential Annual Energy Production for Space Heating From $90^{\circ} \mathrm{C}-150^{\circ} \mathrm{C}$ Hot-Water Convection Systems

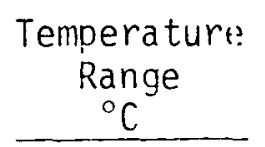

100-119

120-139

140-150
Energy Production

$10^{15} \mathrm{cal} / \mathrm{yr}$ Crude $0 i 1$ Equivalent, $10^{6} \mathrm{bb} / \mathrm{yr}$
35 24 358 2020 $\overline{2473}$ 246 1382

TOTAL

We derived sunply curves for geothernal energv at the point of delivery at several distances from the wellhead (Figure 16). The supply curves are the sum of two costs - the energy production costs and the transmission costs - and they represent the cost of delivering heat to a district heating distribution center. The flatness in the middle of the curves is due to the dominance of the huge blocks of Bruneau-Grandview and k. amath Falls resources. The curves apply to identified rot-water convection systems in the $90^{\circ} \mathrm{C}$ to $150^{\circ} \mathrm{C}$ range. The USGS estimates the undiscovered resource in this temperature range to contain three times the energy of the identified systems.

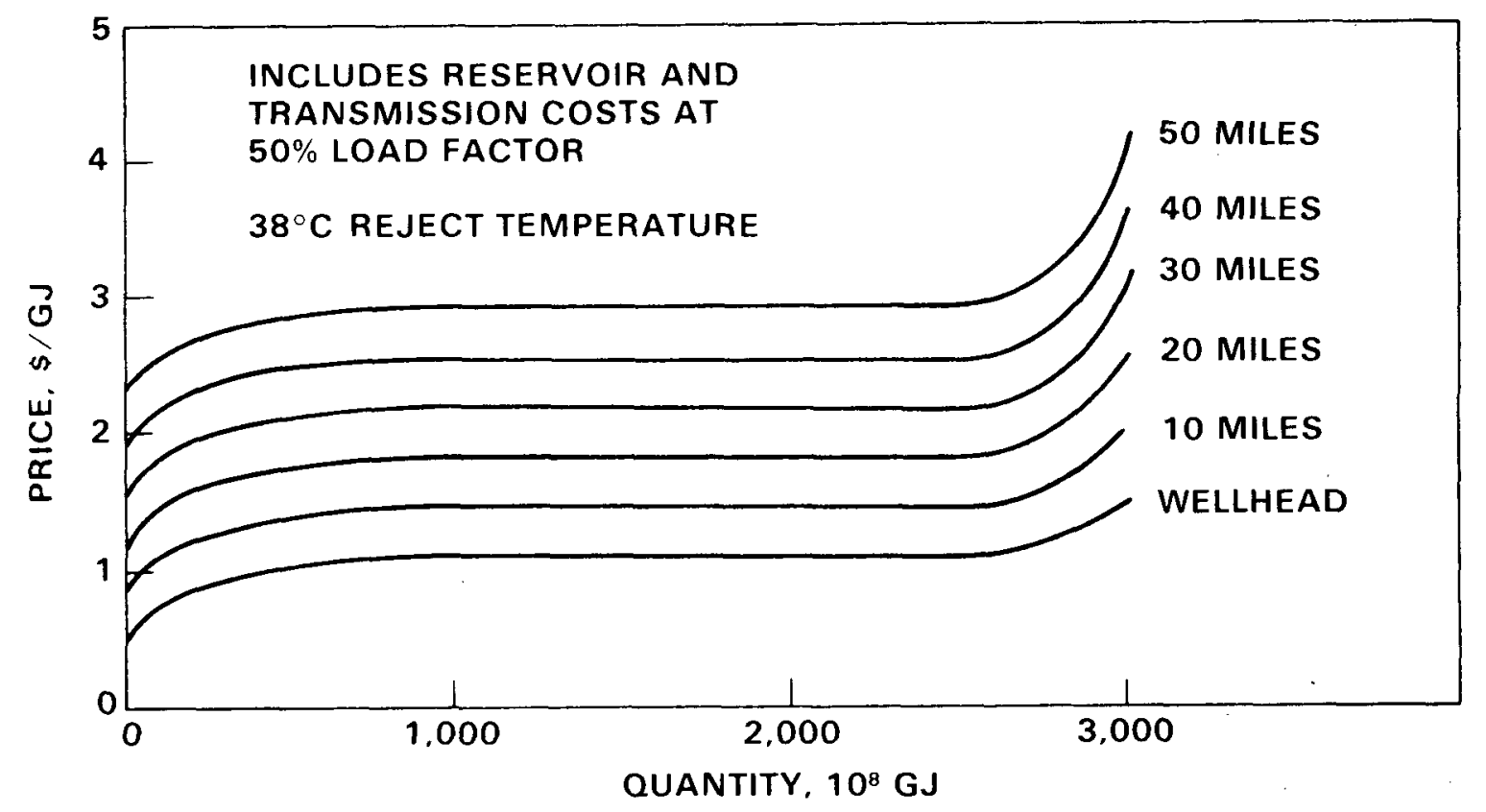

FIGURE 16. Supply Curve at the Point of Delivery for Geothernial Space Heating 
The energy production costs from each resource were determined as a function of fluid temperature, well flovi rate, and well cost (Figure 4). We used a fluid temperature of $110^{\circ} \mathrm{C}$ to represent the $100^{\circ} \mathrm{C}-119^{\circ} \mathrm{C}$ range, $130^{\circ} \mathrm{C}$ to represent the $120^{\circ} \mathrm{C}-139^{\circ} \mathrm{C}$ rance, and $145^{\circ} \mathrm{C}$ to represent the $140^{\circ} \mathrm{C}-150^{\circ} \mathrm{C}$ range. We assumed a drilling cost of $\$ 300,000 / \mathrm{km}$; we used the depth estimated by the USGS to the top of the reservoir to calculate the well cost. We also assumed an average well flow rate of $140,000 \mathrm{~kg} / \mathrm{hr}$ and an average well life of 30 years. Assuming one reinjection well is required for every two production wells, we multiplied the production well cost by 1.5 and used Figure 4 to estimate the energy production cost at the wellhead. We also included a cost provision for a submersible downhole pump of $10 \% / G J$.

The transmission costs were calculated from the following equation:

$$
T C=\frac{\left[\frac{\left(6399 \times F^{-.443} \times T^{-1.456}-0.25\right)}{L F}+0.5\right] \times D}{105.435}
$$

where

$$
\begin{aligned}
T C & =\text { transmission cost, } \$ / \mathrm{GJ} \\
F & =\text { fluid flow rate, } 10^{6} \mathrm{lb} / \mathrm{hr} \\
T & =\text { fluid temperature, }{ }^{\circ} \mathrm{C} \\
L F & =\text { load factor } \\
D & =\text { transmission distance, miles. }
\end{aligned}
$$

This empirical formula was derived from a curve fit of data points calculated using the GEOCITY model at several different combinations of the variables. Our transmission costs include the effect of fluid temperature drop with distance, based on an assumed ambient air temperature of $12^{\circ} \mathrm{C}$. These supply curves and those discussed below assume a fluid flow capacity of $3.175 \times 10^{6} \mathrm{~kg} / \mathrm{hr}$, which corresponds to a 30-inch diameter pipe. We also assumed no elevation change between the resource and the demand.

\section{SUPPLY CURVES FOR DISTRICT HEATING}

We derived supply curves for toth urban and suburban district heating systems. The supply curve for urban district heating (Figure 17) was based on a population density of 12,000 people $/ \mathrm{km}^{2}$, which corresponds to 


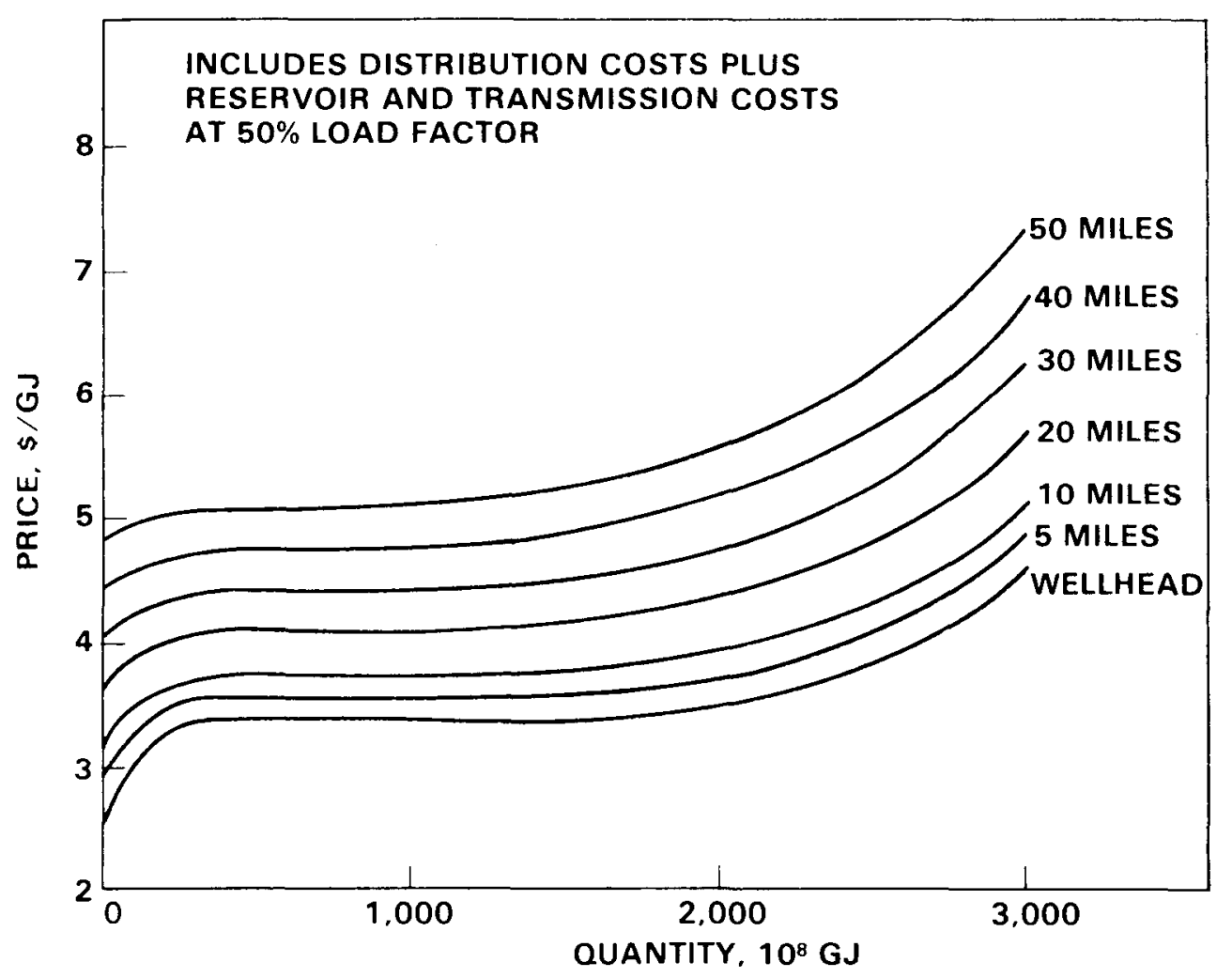

FIGIJRE 17. Sunply Curve for I!rhan District lieating

the zone on Figure 10 labeled "garden apartments." The supply curve for suburban district heating (Figure 18) was based on a population density of 3,000 people $/ \mathrm{km}^{2}$ which corresponds to the zone labeled "suburban residential." The supply curves for geotherrial district heating were based on a random sample of the 222 snall geothernal systemis identified by the USGS. The two larse systems, Bruneau-Crandview and klamath Falls, were treated separately. For each site in this sample we found the average annual heating degree days in the nearest city from the ASHRAE 1970 Guide and Data Cook. (10) We then obtained the distribution system costs as a function of heating degree days from Figure 10. To this we added the production and transmission costs to obtain supply curves for several distances from the wellhead. Comparison of these supply curves with the $\$ 6 / G \mathrm{~J}$ to $\$ 10 / 6 \mathrm{~J}$ expected range of alternative residential heating costs shows that geothermal energy should be supplied competitively for high-density urban district heating from most resources out to 50 miles 


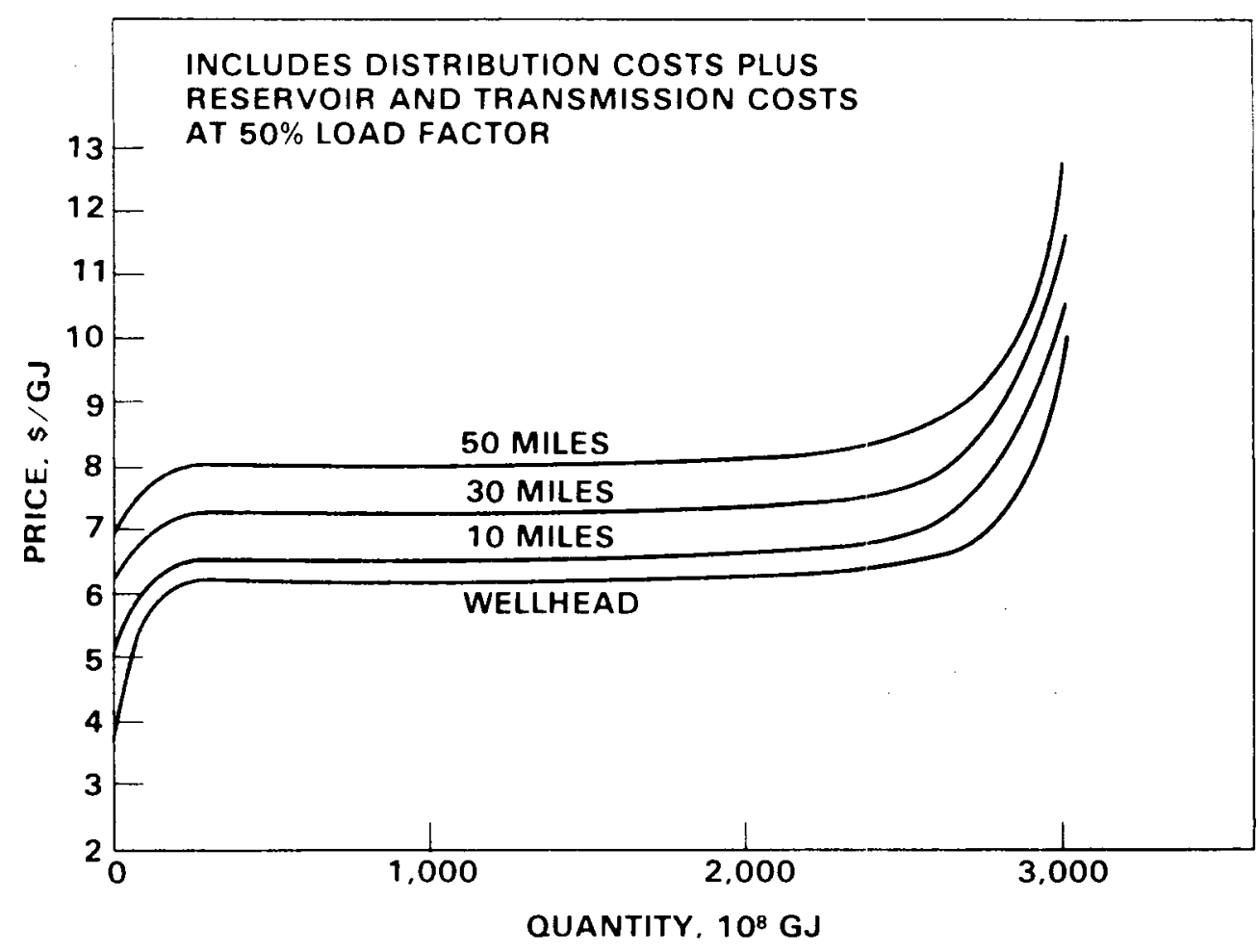

FIGURE 18. Supply Curve for Suburban District Heating

from the we? Thead. For low-density urban and suburban district heating applications, geothernal energy is competitive only at the wellhead with $\$ 6 / C \mathrm{~J}$ heating costs, but is competitive out to 50 miles from most rescurces when heating costs exceed $\$ 8 /$ Gu.

Similar conclusions were reached in an investigation led ry Peter Margen and guided by the Swedish Heat User's Association and Central operating Manacement. (4) They state that "...very long transmission distances (including the distance necessary to connect together the part loads on the regional network) are justified when the heat rates transmitted are sufficiently large. Even $100 \mathrm{~km}$ ( $60 \mathrm{miles}$ ) is not prohibitive when the conditions are favorable."

\section{SUPPLY CURVES FOR PROCESS HEATING}

We derived supply curves for geothermal process heating (Figure 19) at a load factor of $100 \%$. The supply curves reflect the cost of supplying 


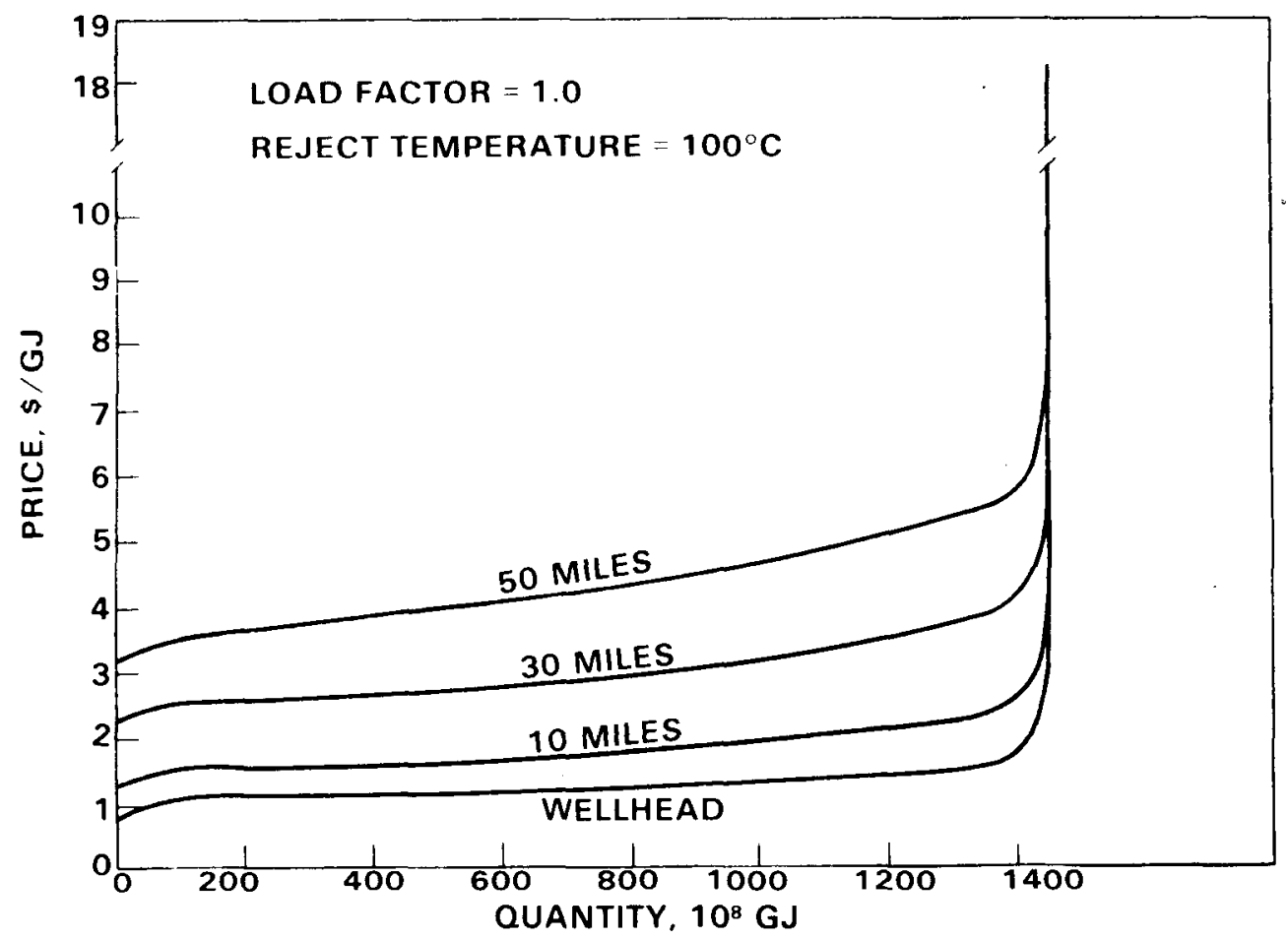

FIGURE 19. Supply Curve for Geothernal Process Heating

geothermal energy for process heat at several distances from the vel lhead. Because of the wide variety of potential process heating applications, these curves include only the costs of delivering the geothermal energy to the plant site. For process heating applications we assuned only the heat above $100^{\circ} \mathrm{C}$ is usable. He adjusted the USGS heat content estimates to $100^{\circ} \mathrm{C}$ base and assumed $25 \%$ recovery of the stored heat at the surface (Table 13). Compared to the $\$ 2 / G J$ to $\$ 3 / G J$ estimated cost of providing process heat from coal, geothermal energy for industrial process heating should be supplied competitively from the $139^{\circ} \mathrm{C}$ to $150^{\circ} \mathrm{C}$ hydrothermal resources out to 30 miles from the wellhead. The sharply rising tail of the sunnly curve applies to the lower tomperature resources.

The high reject temperature for process heating offers the opportunity for other uses of the reject heat. If this waste heat is used beneficially, usually designated in the literature as cascading uses, then process heating costs might be lowered through sharing the production and transmission costs among the end users. 
TABLE 13. Potential Annual lnergy Production for Process l'eating Frolii $90 " \mathrm{C}$ to 150 "C liot-llater Convection Systenis

Temperature

Range

$\frac{{ }^{\circ} \mathrm{C}}{100-119}$

$120-130$

$140-150$

TOTAL

\begin{tabular}{|c|c|}
\hline $10^{15} \mathrm{cal} / \mathrm{yr}$ & $\begin{array}{c}\text { Crude oil Equivalent } \\
10^{\epsilon} \text { bbl/yr }\end{array}$ \\
\hline 10 & 7 \\
\hline 151 & 103 \\
\hline 993 & 679 \\
\hline
\end{tabular}

$\overline{1154}$

$\overline{789}$

\section{POTENTIAL DEMAIIO FOR GEOTIERMAL ENERGY}

The potential demand for geothermal district heating surrounding the 224 hot-water convection systems identified by the USGS is large; over 10\% of the U.S. population resides within 40 miles of the resources (Table 14). We estimate the total denand for space heat within 50 miles of the resources to be $505 \times 10^{6} \mathrm{GJ} / \mathrm{yr}$ (Table 15). This denand requires about $5 \%$ of the potential annual energy production fron the identified $90^{\circ} \mathrm{C}$ to $150^{\circ} \mathrm{C}$ hot-water convecticn systems. About $60 \%$ of the current demand for geothermal district heating can be met for under $\$ 10 / G$ f from these hydrothermal resources. In addition, the demand for process heat near the geothermal resources is comparable in magnitude to the deriand for space heat.

TABLE 14. Current Population Surrounding Geotherma 1 Resources in the $90^{\circ} \mathrm{C}$ to $150^{\circ} \mathrm{C}$ Range

Distance From
Resource, Miles

$0-5$

$5-10$

$10-20$

$20-30$

$30-40$

$40-50$
Tota?

Population

$$
120,000
$$$$
330,000
$$$$
3,950,000
$$$$
6,070,000
$$

$14,210,000$

$9,670,000$

$\overline{34,350,000}$ 
TABLE 15. Potential Existing Demand for District Heating

\begin{tabular}{cr}
$\begin{array}{r}\text { Disiance From } \\
\text { Resource, liiles }\end{array}$ & $\begin{array}{r}\text { Demand } \\
\text { GJ/yr }\end{array}$ \\
\hline $0-5$ & $2,000,000$ \\
$5-10$ & $6,000,000$ \\
$10-20$ & $79,000,000$ \\
$20-30$ & $91,000,000$ \\
$30-40$ & $190,000,000$ \\
$40-50$ & $137,000,000$ \\
& $505,000,000$
\end{tabular}

In order to assess the potential demand for geothermal district heating surrounding the identified geothermal resources, we took a random sample of 20 of the 222 small geothermal systems. For this sample, we determined the population in incorporated communities and unincorporated areas of 1000 or more surrounding the sample locations. (a) For each site we tabulated the population within 0-5 miles, 5-10 miles, 10-20 miles, 20-30 miles, 30-40 miles, and 40-50 miles from the resource. For each circular band we computed the sample mean population and standard deviation. This sample was used to estimate the total population surrounding all 222 locations (Appendix $B$ ). Because of their size, we treated the Bruneau-Grandview and Klamath Falls resources separately. The total population within 50 miles of the $90^{\circ} \mathrm{C}$ to $150^{\circ} \mathrm{C}$ geothemal resources is estimated to be 34 million (Table 14).

The potential existing demand for district heating, based on the climate at the sampled location's, is shown in Table 15. The mix of multifamily and single-family dwellings was determined for each site from the 1970 Census of Housing. Single-family dwellings were assumed to house 3.2 people and to have a required heat load of $11,657 \mathrm{Btu} /{ }^{\circ} \mathrm{F}$ day. Multifamily dwellings were assumed to be garden apartments which contain 60 residences per unit, 2.7 people/residence, and a required heat load of $473,143 \mathrm{Btu} /{ }^{\circ} \mathrm{F}$ day/unit.

(a) From the U.S. Department of Commerce's 1970 Census of Population. 
The estimated costs of meeting the current district heating demand, including production, transmission, and disposal, are shown in Figure 20. The high density urban sector represents only $12 \%$ of the annual demand, or about 10 million barrels of crude oil per year. The low density urtan and suburban sector represents $88 \%$ of the annual demand, or about $74 \mathrm{million}$ barrels of crude oil per year. A.11 of the high density urban demand and about half of the low density urban and sukurban demand can be met at a price beiow $\$ 10 / G \mathrm{~J}$. The cost estimates are based on new developments and do not include retrofitting costs or the incremental costs for construction in established areas.

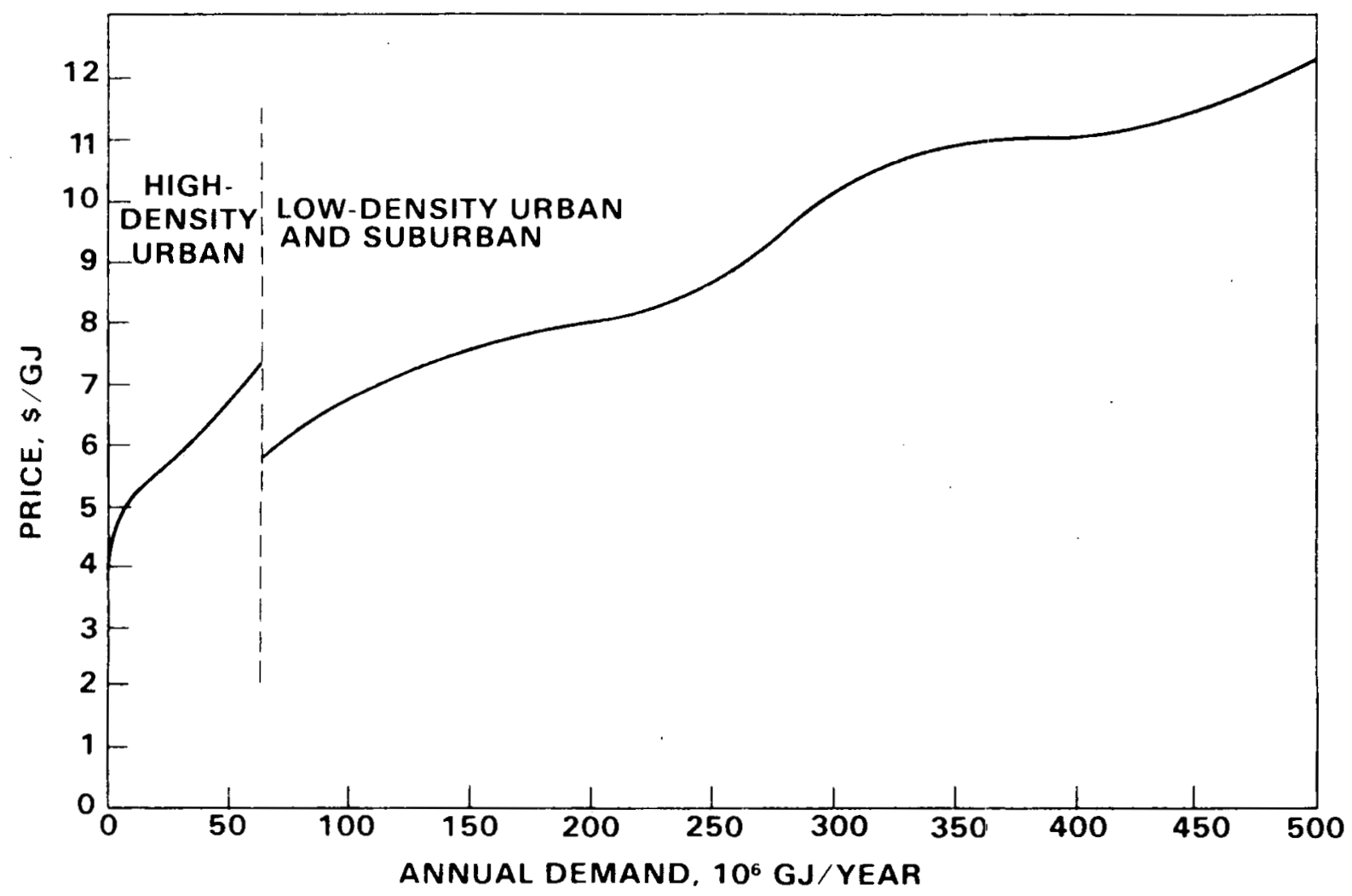

FIGURE 20. Current District Heating Demand

Although the demand for ceothermal district heating is very large, $40 \%$ of the demand probably cannot be met competitively ty the $90^{\circ} \mathrm{C}$ to $150^{\circ} \mathrm{C}$ hydrotherma 1 resources. This demand is from single-family dwellings in 
more distant urban areas and in suburban areas, which are more expensive to supply due to the low population density. Also, much of this deniand occurs in temperate regions where the heating degree days are low, leading to low load factors on the district heating system.

He estimated the potential existing demand for process heating surrounding the geothermal resources to be $872 \times 10^{6} \mathrm{GJ} / \mathrm{yr}$. This estimate is based on population distribution and the classification of heating energy use in the U.S. developed by Dr. Gordon H. Reistad. (3) We included only the categories of use in the temperature ranges $100^{\circ} \mathrm{C}$ to $124^{\circ} \mathrm{C}$ and $125^{\circ} \mathrm{C}$ to $149^{\circ} \mathrm{C}$. To derive an initial estimate of the process heating energy demand, we assumed a direct relationship between the population and the process heating demand. Using ratios of the populations within 50 miles of the geothermal resources to the total U.S. population $(203,000,000$ in 1970), we calculated process heat demands for the various distances from the geothermal resources (Table 16). Although our figures provide only a rough estimate of the notential existing demand for process heating, they do show that the process heating demand is comparable in magnitude to the district heating demand.

\section{TABLE 16. Potential Existing Demand for Process Heating}

\begin{tabular}{cr}
$\begin{array}{c}\text { Distance From } \\
\text { Resource, Miles }\end{array}$ & \multicolumn{1}{c}{$\begin{array}{l}\text { Demand } \\
\text { GJ/Year }\end{array}$} \\
\hline $0-5$ & $3,000,000$ \\
$5-10$ & $8,000,000$ \\
$10-20$ & $100,000,000$ \\
$20-30$ & $154,000,000$ \\
$30-40$ & $361,000,000$ \\
$40-50$ & $246,000,000$ \\
& $\overline{872,000,000}$
\end{tabular}




\section{REFERENCES}

1. D. E. White and 0. L. Williams, eds., Assessment of Geothermal Resources of the United States. I.S. Geological Survey Circular 726, 1975.

2. C. L. Mclonald, C. H. Piloomster, and S. C. Schulte, GicociTY: A Computer Code for Calculating costs of District lleating Using Cieothermal Resources. BNWL-2203, Battelle, Pacific lorthwest Laboratories, Richland, WA, $197 \%$.

3. G. M. Reistad, Analysis of Potential Nonelectrical Applications of Geotherma 7 Energy and Their Place in the Mational Economy. UCRL-51747, Laurence Livermore laboratorv, Perkeley, CA, 1975.

4. P. H. Margen, "District Heating Development Work in Sweden." AE-VS-159, Aktiebolaget Atomenergi, 1975 .

5. J. R. Blacklaw and B. i1. Johnson, A Study of Energy Conservation for the Seattle Area Through the Use of Heat Pumps for Comfort Conditioning. Battelle, Pacific llorthwest Laboratories, Richland, WA, 1973.

6. The Energy gaily, june '2:, 1077.

7. D. L. Anderson, T. J. Foley, and H. A. Reardon, The Regional Analysis of the U.S. Electric Power Industry, Volume 4B, Coal Supply Functions. BiWL-B-415 V4B, Battelle, Pacific Northwest Laboratories, Richland, WA, p. 19, Figure 4, 1975.

8. J. G. Asbury, et al., Frice and Availability of Western Coal in the Midwestern Electric Utility Market, 1974-1982. ANL/ES-38, Argonne Nationa7 Laboratory, Argonne, IL, 1974.

9. Ref. 8, p. 36 .

10. ASHRAE 1970 Guide and Data Book, "Heating, Refrigerating, Ventilating, and Air Conditioning." ASURAE, Hew Yorl., 1970.

11. H. G. Blecker and T. M. Nichols, Capital and Operating Costs of Pollution Control Equipment ifodules. PE-224 536 , ICARUS Corp., Silver Springs, IND, 1973.

12. C. H. Bloomster, et al., GEOCOST: A Computer Program for Geothermal Cost Analysis. BNWL-1888, Battelie, Pacific Northwest Laboratories, Richland, WA, 1975. 
APPENDIX A

HOT WATER FROM COAL 
In order to compare the cost of geothermal district heating with the cost of alternative energy sources, we made an estimate of the cost of supplying hot water from coal-fired plants. He chose coal lecause it is the cheapest alternative available. We made cost estimates for four different cases:

(1) $\quad 9.5 \mathrm{GJ} / \mathrm{hr}$ deriand $950 \%$ load factor,

(2) $9.5 \mathrm{GJ} / \mathrm{hr}$ demand $8100 \%$ load factor,

(3) $190 \mathrm{GJ} / \mathrm{hr}$ demand a $50 \%$ load factor,

(4) $190 \mathrm{Gl} / \mathrm{hr}$ demand $9100 \%$ load factor.

For these calculations we assumed the heating value of the coal to be $10,000 \mathrm{Btu} / 1 \mathrm{~b}$ and the efficiency of the furnace to be $96 \%$. The installed capital costs of the furnace and coal-handling facilities were obtained from Capital and Operating Costs of follution Control Equipment Modules and were escalated to July 1976 dollars. To calculate the annual cost we used a $15 \%$ fixed charge rate, which is typical for investor-owned utilities. Table A-I shows the capital costs and the annual energy costs for the four cases.

The cost of the buildings, foundations, and support equipment were obtained from the GEOCOST (12) nociel. The annual plant expenses, including operating costs, mintenance costs, interim capital replacements, and property taxes and insurance, were also obtained from GEOCOST.

The average of the 1985 projected coal prices shown in Table 10 is $\$ 0.49 / G J$. This cost is added to the annual energy costs shown in Table A-? to get an estimate of the costs of obtaining hot water from coal. For Cases 1 and 3, which have a 50\% load factor, the costs of hot water from coal range from about $\$ 1.50 / G J$ to about $\$ 2.74 / G J$, as shown previously in Figure 2 . 
TAPLE A-1. Annual Energy Costs for Hot Water From Coal

\begin{tabular}{|c|c|c|c|c|}
\hline & Case 1 & Case 2 & Case 3 & Case 4 \\
\hline Heating Demand, Gu/hr & 9.5 & 9.5 & 190 & 190 \\
\hline Load Factor & 0.5 & 1.0 & 0.5 & 1.0 \\
\hline Installed Capital Cost, $\$ 10^{3}$ & 535 & 535 & 4,817 & 4,817 \\
\hline Operating Costs, $\$ 10^{3} / \mathrm{yr}$ & 4 & 4. & 57 & 57 \\
\hline Mairitenance costs, $\$ 10^{3} / \mathrm{yr}$ & 1 & 1 & 12 & 12 \\
\hline $\begin{array}{l}\text { Property Taxes \& Insurance, } \\
\$ 10^{3} / \mathrm{yr}\end{array}$ & 7 & 7 & 78 & 78 \\
\hline $\begin{array}{l}\text { Interim Capital Replacements, } \\
\$ 10^{3} / \mathrm{yr}\end{array}$ & 1 & 1 & 11 & 11 \\
\hline Annual Energy Cost, $\$ / G J$ & 2.25 & 1.13 & 1.06 & 0.53 \\
\hline Average cost of Coal, $\$ / G J$ & 0.40 & 0.49 & 0.49 & 0.49 \\
\hline $\begin{array}{l}\text { Cost of Hot Water From } \\
\text { Coal, } \$ / G J\end{array}$ & 2.74 & 1.62 & 1.55 & 1.02 \\
\hline
\end{tabular}




\section{APPENDIX B}

TOTAL POPULATION WITHIN 50 MILES OF GEOTHERMAL RESOURCES 
In order to determine the total population within 50 miles of the hotwater convection systems identified by the USGS, we took a random sample of 20 of the 222 small systems. Because of their size, we treated the BruneauGrandview and $\mathrm{Klamath}$ Falls resources separately. After tabulating the population within certain fixed distances from each of the 20 resources, we computed the sample mean population within each circular band. We then made a statistical estimate of the total population based on the sample mean population and the sample standard deviation.

Figure $B-1$ shows the locations of the cities and towns within 5, 10, 20, 30, 40, and 50 miles of Norris (Hapgood) Hot Springs in Montana, one of the sites in the random sample. A similar diagram was drawn for each of the other small geothermal systems in our random sample as well as for Bruneau-Grandview and Klamath Falls. The diagrams include all incorporated areas and unincorporated areas of 1,000 or more hased on the U.S. Department of Commerce's 1970 Census of Population, and they are the basis for our calculation of the potential demand for geothermal district heating.

Table $R-7$ contains a list of the 20 systems selected at random and also shows the total population within a specified radius of the geothermal resources. This table was constructed from the individual population diagrams discussed above. For each of the circular bands surrounding a particular resource, we summed the total population within the band. We then determined the sample mean and sample standard deviation within 0-5 miles, 5-10 miles, 10-20 miles, 20-30 miles, 30-40 miles, and 40-50 miles of the resource. Since the USGS identified 222 small geothermal systems (excluding Bruneau-Grandview and Klamath Falls), we calculated the total population for each band as 222 times the sample mean. The total population standard deviation is $(222 / \sqrt{20})$ times the sample standard deviation. The population standard deviation is a large percentage of the total population in a band, ranging from $51 \%$ to $73 \%$, because some of the resources are in unpopulated rural areas and others are within 50 miles of large metropolitan areas. In cases where the areas of two sites overlapped, we assigned the population to the nearest site. 
Name of Resource Norris (Hapgood) H.S.

State Montana

Latitude $\quad 45 \quad 34.6$

Longitude $111 \quad 41$

Cities and towns within $5,10,20,30,40$, and 50 miles of the resource:

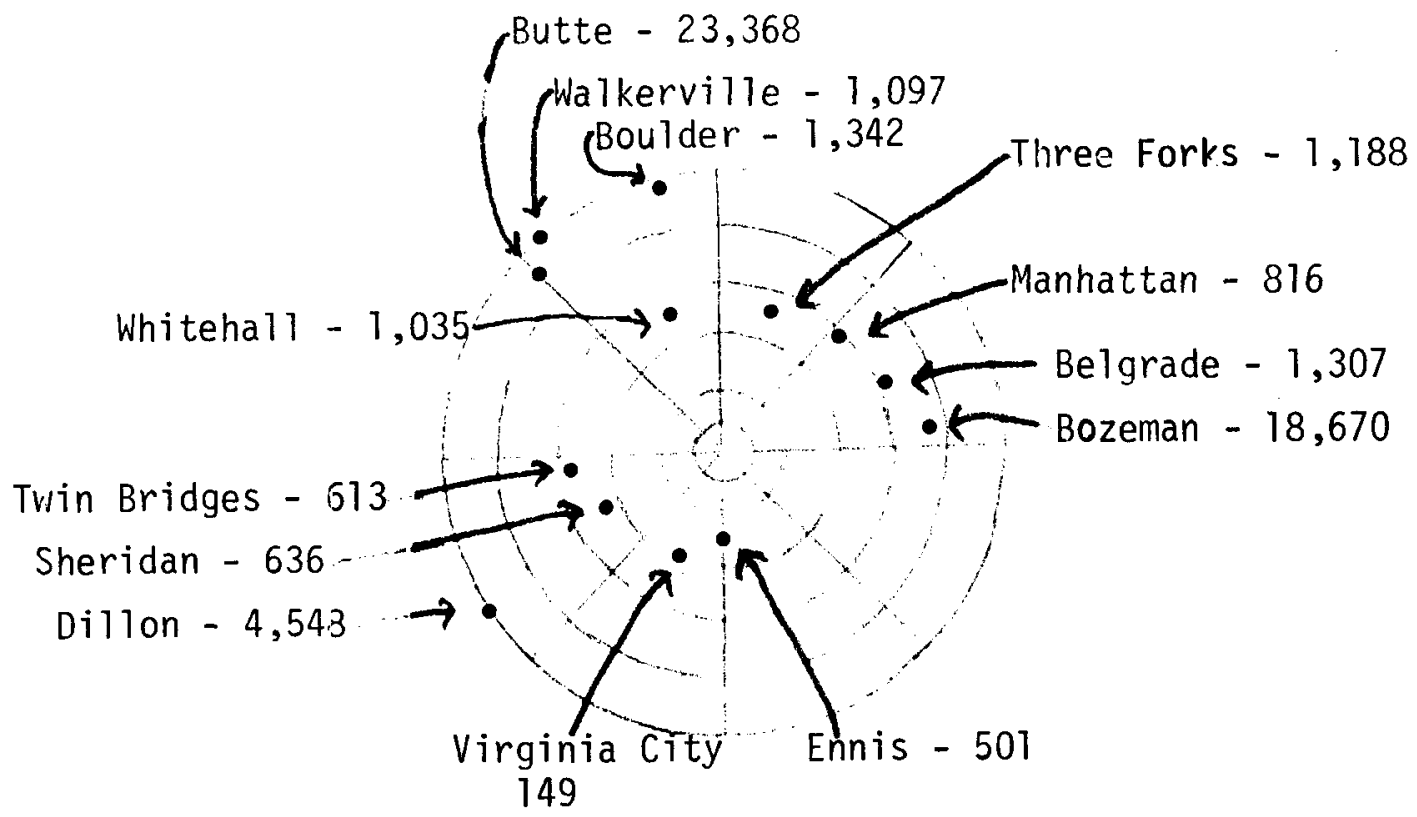

FIGURE B-1. Incorporated Areas and Unincorporater. Areas of 1,000 or More Within 50 Miles of the Resource 
TABLE B-1. Total Population ${ }^{(a)}$ Within Specified Radius of Geothermal Resources

\begin{tabular}{|c|c|c|c|c|c|c|c|c|}
\hline Name of Resource & State & $\begin{array}{c}0-5 \\
\text { Miles }\end{array}$ & $\begin{array}{l}5-10 \\
\text { Miles }\end{array}$ & $\begin{array}{l}10-20 \\
\text { Miles }\end{array}$ & $\begin{array}{l}20-30 \\
\text { Miles }\end{array}$ & $\begin{array}{l}30-40 \\
\text { Miles }\end{array}$ & $\begin{array}{l}40-50 \\
\text { Miles }\end{array}$ & Fotal \\
\hline Bailey H.S. & Alaska & 0 & 0 & 0 & 0 & 10,041 & 2,164 & 12,205 \\
\hline Manley (Baker) H.S. & Alaska & 0 & 0 & 0 & 0 & 0 & 788 & 788 \\
\hline Aetna Springs & California & 0 & 1,882 & 3,173 & 61,856 & 48,597 & 0 & 115,508 \\
\hline Benton H.S. & California & 0 & 0 & 0 & 0 & 3,498 & 3,539 & 7,037 \\
\hline Los Guilicos W.S. & California & 4,112 & 0 & 57,244 & 310,318 & 966,731 & 600,491 & $1,938,896$ \\
\hline Ornbaun Springs & California & 0 & 10,095 & 3,251 & 3,515 & 0 & 4,455 & 21,316 \\
\hline Salt Springs (1) & California & 0 & 0 & 16,659 & 5,492 & 7,676 & 2,214 & 32,041 \\
\hline Seigler Springs & California & 0 & 0 & 3,005 & 1,571 & 3,842 & 4,085 & 12,503 \\
\hline Avalanche Springs & Colorado & 0 & 0 & 3,549 & 4,977 & 5,180 & 12,946 & 26,652 \\
\hline Wagon Wheel Gap & Coiorado & 0 & 653 & 0 & 1,569 & 6,830 & 2,260 & 11,312 \\
\hline Dutch Frank Springs & Idaho & 0 & 0 & 164 & 14 & 80,937 & 3,615 & 84,730 \\
\hline Near Chalk Mine & Idaho & 0 & 114 & 4,421 & 5,666 & 33,979 & 4,624 & 48,804 \\
\hline Near Cove School & Idaho & 0 & 383 & 1,075 & 5,055 & 7,236 & 15,650 & 29,399 \\
\hline Near Riverdale & Idaho & 3,310 & 2,211 & 1,810 & 40,588 & 23,367 & 4,030 & 75,316 \\
\hline Riggins H.S. & Idaho & 533 & 0 & 0 & 0 & 4,241 & 3,806 & 8,580 \\
\hline Norris (Hapgood) H.S. & Montana & 0 & 0 & 650 & 4,288 & 19,977 & 30,355 & 55,270 \\
\hline Howard H.S. & Nevada & 0 & 0 & 0 & 0 & 0 & 0 & c \\
\hline Ritter H.S. & Oregon & 0 & 0 & 357 & 0 & 5,278 & 1,962 & 7,597 \\
\hline Crystal H.S. & Utah & 2,820 & 14,309 & 259,300 & 101,094 & 49,717 & 98,769 & 526,009 \\
\hline Sulphur Creek H.S. & Wàshington & 0 & 0 & 1,094 & 573 & 3,084 & 75,419 & 80,170 \\
\hline $\begin{array}{l}\text { Sample Mean } \\
\text { Sample o } \\
\text { TOTAL Population }(b) \\
\text { TOTAL Population } \sigma(c)\end{array}$ & & $\begin{array}{r}539 \\
1,231 \\
119,658 \\
61,108\end{array}$ & $\begin{array}{r}1,482 \\
3,686 \\
329,004 \\
182,976\end{array}$ & $\begin{array}{r}17,788 \\
56,803 \\
3,948,936 \\
2,819,741\end{array}$ & $\begin{array}{r}27,329 \\
69,714 \\
6,067,038 \\
3,460,652\end{array}$ & $\begin{array}{r}64,011 \\
208,143 \\
14,210,442 \\
10,332,366\end{array}$ & $\begin{array}{r}43,559 \\
130,298 \\
9,670,098 \\
6,468,085\end{array}$ & $\begin{array}{r}154,708 \\
424,208 \\
34,345,176 \\
21,057,986\end{array}$ \\
\hline Population o/Total Pof & pulation, $\%$ & 51 & 56 & 71 & 57 & 73 & 67 & 61 \\
\hline
\end{tabular}

(a) Includes all incorporated areas + unincorporated areas of 1,000 or more.

(b) Total population $=(222) \times$ (sample mean)

(c) Population $\sigma=(222 / \sqrt{20}) \times($ samole $\sigma)$ 
No. of

Copies

OFFSITE

1 ERDA Chicago Patent Groun Energy Research \& Development fidministration

Argonne, IL 60439

A. A. Churm

10 Division of Geothermal

Energy

Energy Research \& Development Adninistration

Washington, D.C. 20545

I. Paik

451

ERDA Technical Information Center

1 Richard L. Anglin, Jr. 2165 East Orange Cirove Blvd.

Pasadena, CA 91104

1. IIr. Roger Aureille

Chef de La Division Technique des Energies Ilouvelles

Department Systemes Energetiques

Electricite de France

Etudes et Recherches

6, Quai Watier

78400 Chatou

France

1 : Empresa Macional de Luz y Fuerza Apdo. 55

îanagua, D.N.,

Nicaraqua, C.A. Ing. Roberto Vega P., Vice Presidente

1 Energetics Marketing \&:

Tanagement Associates, Ltd.

P.0. Box 159 ?

So. Pasadena, CA 91030

Albert $T$. Holmes II
No. of

Copies

DFFSITE

1 Japan Geothermal Energy

Association

Yurakucho Denki Building

1-7-1 Yuraku-Cho Chiyoda-

$\mathrm{Ku}$

Tokyo, Japan

1 Mr. Willard E. Johnson,

Manager, Energy Division

WESTEC Services, Inc.

1520 State Street

San Diego, CA 92101

1. Mr. Karl Omar lonsson

Civil Engineer

FJARHITUN HF.

Alftanyri 9

Reykjavik, Iceland

1 Dr. 0. Kapnelmeyer

Federal Institute for

Geosciences \& Natural

Resources

P.0. Box 510153

D.-3 Hanover 51

Federal Reputlic of

Germany

1 Mr. Gunnar Kristinsson

Chief Engineer

Reykjavik Municipal District

Heating Service

Drapuhlid 14

Reykjavik, Iceland

1 Dr. Phil LaMori

Electric Power Research

Institute

3412 Hillview Avenue

Palo Alto, CA 94304 


\section{DISTRIBUTION (Continued)}

No. of

Copies

OFFSITE

$1 \quad M r$. Tod Larson

University of California

Dry-Lands Research Institute

Riverside, CA 92521

1 Yukio Nakamura

Jet Propulsion Laboratory

California Institute of

Technology

4800 Oak Grove Drive

Pasadena, CA 91103

$1 \quad$ New Zealand Electricity

Department

Rutherford House

P.0. Box 12144

Wellington, New Zealand John F. Boshier

$1 \quad$ W. Ogle

3801 B West, 44th Avenue

Anchorage, AK 99503

1 Dr. Gudmundur Palmason

Vational Energy Authority

Laugavegur 116

Reykjavik, Iceland

1 Vasel Roberts

Electric Power Research

Institute

3412 Hillview Avenue

Palo A1to, CA 94304

$1 \quad$ P. Sangnier

Conseiller Scientifique

Ministere de L'Industrie

et de La Recherche

35 Kue Saint-Dominique 75700

Paris, France
No. of

Copies

OFFSITE

1 Richard Arlen Snith

P.0. Box 35-K

Tracey's Landing, MD 20869

$1 \quad$ Mr. Siaurdur Thordarson

Civil Engineer \& Partner

Thoroddsen and Partners

Armula 4

Reykjavik, Iceland

1 Turner, Collie, \& Braden,

Inc.

P.0. Box 13089

Houston, TX 77019

Tom k'leeman

1 Syd Willard

Energy Pesources

Conservation \& Develop-

ment Commission

1111 Howe Avenue

Sacramento, CA 95825

1 Thomas C. Wright

The Futures Group

124 Hebron Avenue

Glastonbury, CT 06033

ONSITE

ER.DA Richland Operations Office

P. G. Holsted

62 Battelle-Northwest

C. H. Bloomster (20)

J. B. Burnham

N. E. Carter

J. W. Currie

Dist. -2 


\section{DISTRIBUTION (Continued)}

No. of

Copies

ONSITE
Battel le-Northwest

L. J. Defferding

D. E. Deonigi

L. L. Fassbender (10)

J. C. Fox

H. D. Huber

G. H. Krauss

J. H. Litchfield

C. L. McDonald (10)

W. R. McSpadden

E. L. Owzarski

S. C. Schulte

R. A. Walter

Economics Library (3)

Technical Information (5)

Technical Publications 